\title{
Sovereign Credit Rating Announcements and Liquidity Shocks in the Lebanese Daily Foreign Exchange Market
}

\author{
Samih Antoine Azar \\ Professor \\ Faculty of Business Administration \& Economics \\ Haigazian University \\ Mexique Street, Kantari, Beirut, Lebanon \\ E-mail: samih.azar@haigazian.edu.lb
}

\begin{abstract}
Sovereign credit rating announcements are usually unexpected events that can affect local financial markets either favorably or detrimentally. In Lebanon, the credit outlook witnessed a deteriorating trend since the mid of the year 20I6. The major hypothesis of this paper is that the reaction to the bad credit rating announcements is statistically significant, although ephemeral, delimited to just a few days. It is through the liquidity channel that these announcements create uncertainty and affect the economy. There are two related hypotheses: (I) illiquidity shocks impact undesirably the financial markets, and (2) credit rating announcements are accompanied by a surge in illiquidity. Since the impact of these announcements is ephemeral it should be assessed by high-frequency data, or at most by daily financial data. The domestic foreign exchange market is an ideal place to study this impact. Fortunately, the central bank of Lebanon has lately made available daily foreign exchange rates for six major currencies beginning in 20I0. This defines six multiple regressions that are constructed to differentiate between the short-run and the long-run responses to illiquidity. The empirical results show that the above two hypotheses are strongly supported. Moreover, it matters little whether the event window is 3, 4 or 5 days.
\end{abstract}

Keywords: Credit Rating, Illiquidity, Event Study, Foreign Exchange Market, Daily Data, Lebanon.

JEL Classification: GI4, F3I, C58, C38.

\section{Introduction}

Lebanon has experienced after mid-July 2016 a deteriorating sovereign credit rating by the three major US credit rating agencies (Fitch, Moody's, and Standard \& Poor's). Before that date, credit ratings oscillated between more favorable to less favorable, and were little observed and followed up. The build-up of bad credit rating news since mid-July 2016 must have left its mark on the financial markets, or even in the memory of the public, and may have been instrumental in the general loss of confidence that sparked during the period before, and during the crisis, that started in October 2019. One of the most visible segments of the Lebanese financial markets is the foreign exchange market, and it is to this market that we turn our attention to assess the extent of the impact of such bad news. Fortunately, the central bank of Lebanon has been publishing statistics on daily foreign exchange rates of the major currencies since January 4, 20I0. These statistics comprise the asking, the bid, and the mid prices of the following currencies against the Lebanese pound: the Australian dollar (AUD), the Canadian dollar (CAD), the Swiss franc $(\mathrm{CHF})$, the euro (EUR), the sterling pound (GBP), and the Japanese yen (JPY). In the statistical release, the US dollar is assumed to be at I,507.50 Lebanese pounds, which implies that the data on the above six foreign currencies are indirect quotes of cross rates, and not of the exchange value of the Lebanese pound per se. That is why we divide all foreign exchange rate data by $1,507.50$ to get the true cross rates.

Liquidity is the ease of placing large trades quickly and at a low cost (Banti, 2016). We define our measure of liquidity to be the spread between the asking price and the bid price. Thereafter illiquidity is always referred to by the term spread. We have two hypotheses: (I) liquidity shocks are priced in the foreign exchange market, and (2) sovereign credit rating announcements increase the uncertainty in the financial markets and, thereby, affect adversely the liquidity of this market. Our research design is similar to the one in event studies, originally introduced by Fama et al. (I969). Other early applications include (Jaffe, 1974; Ibbotson, 1975; Ellert, 1976; Masulis, 1980). For a more recent analysis of the involved econometrics see (Kothari \& Warner, 2007; Betton et al., 2008). We assume that credit rating announcements have an ephemeral effect on daily exchange rates and that this effect dissipates in the wake of three, four or even five open days. While a window of three to five 
days is arbitrary, despite being reasonable elsewhere ${ }^{\mathrm{I}}$, we believe it is a conservative estimate and just enough to encroach the incoming news of an event into the public memory. For this to happen that quickly we assert that bad news gets usually a privileged place on the media.

\section{The literature}

The proposition under scrutiny is that returns should be higher for less liquid assets, to compensate the investor for the added transaction and trading costs. This proposition was applied mostly to stocks, and less frequently to bonds (De Jong \& Driessen, 2012; Bai et al., 2019; Dididüzgün et al., 2020) but rather scarcely to foreign exchange rates (Banti et al., 20I2; Mancini et al., 20I3; Banti \& Phylaktis, 2015; Banti, 20I6). Early papers on the subject are found in Amihud \& Mendelson (I986a, I986b). Other central studies are Pástor \& Stambaugh (2003) for the US, and Foran \& O'Sullivan (20I4); Foran et al. (20I4) for the UK, and Zhong \& Takehara (2019) for Japan, and Banti et al. (2012); Amihud et al. (2015); Banti \& Phylaktis (20I5) for international evidence. While the general intent of the literature is to test for a priced liquidity characteristic, Avramov et al. (2016) relate anomalous momentum profits to increased liquidity, and they find that these profits become significant once liquidity effects are taken into consideration.

Amihud \& Mendelson (1986a) use a linear-log regression specification while Amihud \& Mendelson (I986b) use a linear-linear regression specification. Both papers find evidence that liquidity is priced in the market, after adjusting for systematic risk (or beta risk). For example, and on average, a I\% increase in the spread will generate a 0.2 I I\% increase in monthly risk-adjusted excess returns. The relation is therefore positive between illiquidity and stock returns, but, also, it is concave, with bid-ask spreads in percent $(s)$ getting amortized over a longer holding period (from 0 to $T$ ), thus creating a clientele market, whereby long-term investors end up holding less liquid financial assets. This can be formalized by the following relations, where $r$ is the continuously compounded rate of return, and $P$ is the stock price:

$$
P_{T} /\left[P_{0}(1+s)\right]=e^{r T}
$$

\section{(2) holding period return $=(1 / T) \operatorname{LOG}\left(P_{T} / P_{0}\right)=r+(1 / T) * L O G(1+s) \cong r+(1 / T) * S$}

The last approximate equality arises because $S$ is close to zero. Amihud and Mendelson conclude that liquidity is crucial for asset pricing and that its effect does not contradict or invalidate market efficiency as defined by Malkiel \& Fama (1970). On the contrary, liquidity can explain the equity premium puzzle (Mehra \& Prescott, 1985) and the uncovered interest rate parity puzzle (Froot \& Thaler, 1990).

The theory of asset pricing was extended to incorporate the liquidity effect in what was called the "Liquidity-adjusted CAPM" (Acharya \& Pedersen, 2005) set up a model with four betas. The following comments borrow from (Amihud \& Mendelson, 2015; Kumar \& Misra, 2019). The first is a systematic risk beta, which has a positive risk premium. The second has a positive risk premium and is the liquidity beta identified by the "commonality" of liquidity (Chordia et al., 2000) and stands as compensation for holding a security that becomes illiquid when the market becomes illiquid. The third beta is market-wide or systematic liquidity and is usually negative, because of a sensitivity of asset returns to market-wide illiquidity: investors are willing to accept a lower return on an asset whose return is higher in states of high market illiquidity. In other terms, investors prefer assets whose prices fall less with a rise in market illiquidity. The fourth beta arises because investors are willing to accept a lower expected return on a security that is liquid in a down market, and the risk premium is generally negative. In other terms, investors prefer assets whose illiquidity rises less when there is a market-wide decline in prices. Hence the last three betas are the covariance of the stock's liquidity with aggregate liquidity, the covariance of stock returns with aggregate liquidity, and the covariance of the stock's liquidity with the market return, all measured as a proportion to the variance of the market portfolio in net returns, i.e. after trading costs and after price-impact costs (Amihud \& Mendelson, 2008). Zhong \& Takehara (2019) apply the liquidity-adjusted CAPM to Japan. They derive aggregate liquidity using principal components analysis (PCA), which, the authors argue, is superior to just averaging. Kumar \& Misra (2019) make use of two additional idiosyncratic risk premiums in their cross regression equation. In a similar vein, Guo et al. (2017) argue that aggregate idiosyncratic risk is priced (negatively). Akbas et al. (2011); Kumar \& Misra (2019) adopt the same definition of illiquidity as in Amihud (2002) which is the average ratio of the daily absolute return to the dollar trading volume on that day for asset $i$ in month $t$ :

(3) cost of trading or illiquidity $=I L L I Q=\left(1 / D_{i t}\right) \sum_{d=1}^{D_{i t}}\left\{\left|r_{i t d}\right| /\left(P_{i t d} V_{o l} l_{i t d}\right)\right\}$

where $r_{i t d}$ is the return of stock $i$ on day $d, P_{i t d} V o l_{i d}$ is the dollar trading volume for stock $i$ on day $d$, and $D_{i t}$ is the number of days. Other researchers have calculated illiquidity to be the number of zero daily returns in a given month (Bekaert et al., 2007). Other illiquidity indicators are studied in Marcelo et al. (2015).

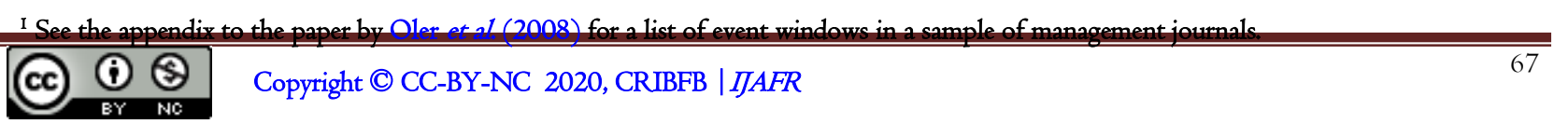


One would expect that the relation between liquidity and expected returns to be more pronounced in emerging markets which are characterized by less liquid equity markets relative to advanced countries. This is in fact what is discovered (Jun et al., 2003; Bekaert et al., 2007). Some researchers have extended the investigation of the liquidity effect in tiny or small developed countries like Portugal (Marcelo et al., 2015; del Mar Miralles-Quirós et al., 2017). They find mixed evidence for commonality, or the impact of systematic liquidity risk, but friction illiquidity is significantly priced. What is peculiar is that more (friction) liquid stocks have higher returns, or, at the very least, have less negative returns.

\section{The Econometric Model}

The spread, i.e. the asking price minus the bid price, is denoted by S. The spread of a given currency is denoted as $\mathrm{S}$ followed by the three letters identifying the currency. For example, and for the British pound, the spread takes the following label: SGBP. In general $\mathrm{S}$ is the spread and the three stars are the currency code. The bid price is denoted by BID with the three stars

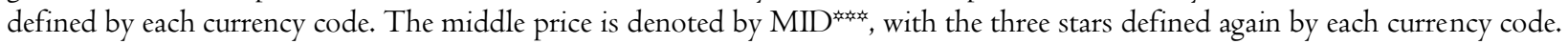
The percent spread is therefore defined as $S^{\text {divided by MID }}$ and that for each one of the six currencies: Australian dollar (AUD), Canadian dollar (CAD), Swiss franc (CHF), euro (EUR), British pound (GBP), and Japanese yen (JPY). The data spans the daily period from January 4, 2010, till October 16, 2019, at the eve of the Lebanese popular uprising, and is retrieved from the web site of the central bank of Lebanon. The data points are 2,382 observations per variable, falling to 2,38I observations when first-differences are applied with $\Delta$ being the first-difference operator. LOG is the natural logarithm operator. $\Delta L O G(B I D * * *)$ is the term that stands for the log-returns of the bid price of the currency

The sovereign credit rating announcements are on the dates in Table I. Between July I4, 20I6, and October I, 20I9, there were nine downgrade announcements from the three US credit rating firms (Fitch, Moody's, and S \& P). The frequency numbers show 3 downgrades by Fitch (July I4, 2016; December 8, 2018; and August 23, 2019), 4 downgrades by Moody's (August 25, 2017; December 13, 2018; January 21, 2019; and October I, 2019), and two downgrades by Standard \& Poor (September 2, 2016; and March I, 2019). These nine downgrade announcements had a significant news impact, were greatly publicized, and were one of the reasons why confidence and trust in the political authorities and the incumbent political lords, in power for almost decades, eroded slowly until the disturbances exploded on October 17, 2019.

The events considered in this study are these nine downgrade announcements. Their effect is deemed to be temporary, bursting initially and waning thereafter. To be temporary these events should be exogenous surprises. That is the major assumption of this paper.

These announcements might have left a lasting negative impact, but we assume that this lasting impact remained dormant in the unconscious part of the brain until the collapse on October 17, 2019. Based on this underlying assumption of the briefness of reaction we have decided to choose an event window of three days. However, event windows of four and five days (or one open week) were attempted. We chose to report the results for both three and five days. The results for four days, which are not materially different from the other two, are available from the author. There is a way to compare multiple regressions with the same dependent variable by looking at the statistical information criteria. These favor the five days event window in four out of six cases, the exceptions being the EUR and the JPY regressions.

An ephemeral impact for the credit announcements and the non-stationary statistical behaviors of both $L O G(B I D * *$ $*)$ and $S * * *$, as will be shown later, dictates the structure of the econometric procedure adopted. The (non-linear) regression model selected, which is a non-linear Error-Correction Model (ECM), is as follows:

$$
\begin{gathered}
\text { (4) } \Delta L O G(B I D * * *)=c(1)(\Delta S * * *)+c(2)(D u m m y)(\Delta S * * *) \\
+c(3) \operatorname{LOG}(B I D * * *(-1))-c(3) c(4)-c(3) c(5)(S * * *(-1))+c(6) A R(1)+\epsilon
\end{gathered}
$$

In this regression, $\triangle L O G(B I D * * *)$ is the currency log-return, calculated from daily bid prices, Dummy stands for an indicator variable taking the value $\mathrm{I}$ in each event window and zero otherwise, and $A R(1)$ is a first-order autoregressive variable. $c(1)$ is the temporary or short-run effect of illiquidity shocks which is the short-run price of illiquidity, $c(2)$ is the ephemeral or short-run effect of the rating announcements, in interaction with the illiquidity shocks on the currency log return, $c(3)$ is the coefficient on the lagged error-correction residual, which represents the adjustment to the long-run, $c(4)$ is the longrun effect of illiquidity on the currency $\log$ return, and $\epsilon$ is the regression residual. Since the six currency spreads $S * * *$ are found to be non-stationary, as mentioned earlier, then $\Delta S * * *$ is indeed an illiquidity shock. In the literature, the spreads are found to be highly persistent (Banti, 2016) which, at the limit, follows a non-stationary process.

There are six currency pairs against the US dollar; therefore, six separate multiple non-linear regressions. The purpose of this paper is twofold. The first purpose is to find out whether illiquidity is priced in the short-run and the long-run in the foreign exchange market. In other terms $c(1)$ and $c(4)$ should be positive and statistically significant. These two hypotheses 
will be confirmed empirically later. The second purpose is that credit rating announcements are ephemeral surprises that tend to increase uncertainty and illiquidity, which, in turn, produce a heightened illiquidity shock. In other terms, $c(2)$ should be positive and statistically significant. A subsidiary hypothesis, which emerges from the econometric results, is whether the shortrun effect of illiquidity is equal to the long-run effect. Evidence shows that the two effects are indeed statistically no different from each other.

\section{Descriptive Statistics}

There are two categories of descriptive statistics, the ones that pertain to level and log-level variables, and the ones that pertain to first-differences and log-returns. The first set of variables includes the following: the levels and log-levels of the six cross rates, mainly of the bid prices, and their liquidity spreads. The KPSS unit root tests reject the null hypothesis of stationarity, the minimum test statistic being 0.867987, which is for LOG(BIDCHF), while the I\% marginal significance level is 0.739000 . Despite that, and although non-stationary variables do not have constant means and standard deviations, we report summary statistics on them. Many unsophisticated readers would be interested in these statistics.

It should be mentioned that all the variables are divided by I,507.50, the currency price of the US dollar in Lebanese pounds, and this implies that these ratios belong to international quotations of the pairs of the cross rates in the Lebanese foreign exchange market. The calculated level averages of the six pairs of BID*** are as follows: 0.85668I (BIDAUD), 0.868364 (BIDCAD) I.03952I (BIDCHF), I.22834I (BIDEUR), I.4708I3 (BIDGBP), and 0.0I0062 (BIDJPY). These values carry some degree of indication, although they are statistically flawed. The same can be said about the standard deviations. The highest standard deviation is for the GBP cross rate, which is as expected because it has the highest average. But, surprisingly, the lowest is for the CHF cross rate, while the lowest average, excluding the JPY, is for the AUD cross rate. The descriptive statistics for the averages of $B I D * * *$, their standard deviations, median, maximum, and minimum are referred in Table 2. The null of normality is rejected for all six pairs.

The descriptive statistics for the six pairs of logs of the bid prices $L O G(B I D * * *)$, in Table 3 , have naturally the highest mean for the British pound (0.381098), and the lowest mean, excluding the JPY, is for the AUD. However, the highest standard deviation is for the JPY (0.I45922), and the lowest is, again surprisingly, for the CHF (0.056549). The null of normality is again rejected. Other summary statistics are in Table 3.

The descriptive statistics for the six pairs of the spreads $S * * *$, in Table 4, show that the highest mean spread is for the British pound, and the lowest, excluding the JPY, is for the AUD. This ranking is as expected. The standard deviations have the highest figure for the GBP (0.001217), and the lowest figure is for the CHF (0.0005I5). Other summary statistics are in Table 4. Normality is rejected for the six spreads.

The second category of descriptive statistics is on derived first-differences and log-returns. Three sets of six variables each are considered: the change in spreads (ask minus bid prices), the percent spreads (ask minus bid prices as a ratio to the midprice), and the log-returns on the six cross rates. The variables in the first set are divided by I,507.50. The KPSS test finds all I8 series ( six cross rates with three sets of variables) stationary in distribution. The highest test statistic is 0.173998 while the lowest critical statistic for a $10 \%$ marginal level of significance is 0.347000 . Since all series are stationary then a t-test on the mean is valid. The null hypothesis for such a test is a zero mean, while the alternative hypothesis is a non-zero mean. The null hypothesis fails to be rejected for all six changes in the spreads, and all six log-returns of each pair of currencies, the minimum pvalues being 0.3337 and $0.338 I$ and they pertain to the euro cross rate. See Table 5 for the changes in the spreads, and Table 6 for the log-returns. In these two tables, all series are non-normal except for the Japanese yen. Other summary statistics are available in these two tables.

A zero mean for the first-differences of the spread, and a non-stationary behavior of the spreads, imply that the firstdifference of the spread is indeed an unanticipated shock to illiquidity. A zero mean for the log-returns implies that no one of the cross rates have witnessed a depreciation or an appreciation on average. The null of a zero-mean is rejected at an extremely low marginal significance level for the percent spreads (the ratios of the spreads to the mid-prices) for all six cross rates (Table 7). Out of the six means, one is lowest (0.00862 for the JPY), one is the next lowest (0.008623 for the CAD), and the four rest are all equal to 0.008624 . The medians are the same as the means except for the JPY which has a median of 0.008660 . The maxima are all within a tight range, between 0.008629 and 0.008632 , except for the JPY which has a maximum of 0.009397 . The minima are all also within a tight range, between 0.008615 and 0.008619 , except for the JPY which has a minimum of 0.007886. The standard deviations are all comparable, between $1.86 \times \mathrm{IO}^{-6}$ and $3.29 \times 10^{-6}$, except for the JPY which has a standard deviation of 0.000280 . There is little evidence that the euro and British pound are more liquid (Banti, 2016). All normality tests are failed. See Table 7 . The above shows that the percent spread are close to being the same irrespective of the currency pair. Compared to the data for five currency pairs (without the CAD) in Banti (2016) the percent spreads in Lebanon are all higher than those in the international markets by a factor of I3.7 at least (for AUD) and by a factor of 27.8 at most (for GBP). 


\section{Empirical Results}

The statistical evidence upon the estimation of the econometric model, equation (4), is reported in Tables 8 to I3. Each table is for a given cross rate, starting from the Australian dollar (AUD) and going to the Japanese yen (JPY). Also, each table is divided into two parts, one part that presents the results for a 3-day event window, and the other part for a 5-day event window. Above each part the empirical procedure and the model formulation are detailed. In all I2 regressions, standard errors are robust (Newey \& West, 1987) except for the two Swiss franc regressions (Table 10). The results are comparable for the first five tables (Table 8 till Table I2). The JPY regressions are peculiar. For example, all the adjusted R-Squares are higher than 0.97743I while the R-Square of the JPY regressions is meager $0.0236 \mathrm{I} 2$ and 0.024022 . Moreover all regressions are estimated with an AR(I) specification, except for the two JPY regressions which have insignificant coefficients on the AR(I) variable. All long-run coefficients, i.e. $c(5)$, are within reasonable bounds except in the two JPY regressions. Lastly, all coefficients on the interactive variable, i.e. $c(2)$, are statistically significant except for the coefficients in the two JPY regressions. Hence credit rating announcements do not interact with liquidity shocks and are neutral in the two JPY regressions. Nonetheless, the adjustment to the long-run is fast in the two JPY regressions, hovering around 29 open days. For all these reasons the two JPY regressions are deemed anomalous, and will not be built upon in the analysis. However, they are reported just for the sake of consistency.

In Table 8 the empirical results for the case of the Australian dollar are presented. The two regressions in the table produce similar results. We shall examine the 4-day window regression because it has the lower values of the information criteria (Akaike, 1973; Schwarz, 1978; Hannan \& Quinn, 1979). The two effects of the illiquidity shocks, short-term and long-term, are I3I.6398 and I34.8870 respectively and are highly significant statistically with actual p-values less than 0.00005. A Wald test for the null of equality fails to be rejected with an actual two-tailed p-value of 0.4194 (Table I4). From this is inferred that the short-run and the long-run effect of liquidity shocks are of the same magnitude, something which is challenging because, in economic theory, the long-run adjustment is usually higher than the short-run one. Anyway, the hypothesis that liquidity shocks are priced is strongly supported. The second hypothesis, that credit rating announcements adversely affect liquidity, is also well supported, with an impact of 24.80212, and carries a t-statistic of 5.808662. Relatively speaking the effect of credit rating announcements on the AUD log return is almost $19 \%$ of the effect of straight and ordinary liquidity shocks. The adjustment to the long-run, which is measured by $-1 / c(3)$, is 134.5526 open days, a relatively high figure and a relatively slower adjustment. The coefficient on the $A R(1)$ variable is negative and significant. Finally, the adjusted R-Square is quite high for daily data and is 0.978955 .

In Table 9 the empirical results for the case of the Canadian dollar are presented. The two regressions in the table produce quite similar results. We shall examine the 4-day window regression because it has the lower values of the information criteria (Akaike, 1973; Schwarz, 1978; Hannan \& Quinn, 1979). The two effects of the illiquidity shocks, short-term and longterm, are I29.3057 and I33.3054 respectively and are highly significant statistically with actual p-values less than 0.00005. A Wald test for the null of equality rejects it with an actual two-tailed p-value of 0.0392 (Table I4). From this is inferred that the short-run and the long- run effect of liquidity shocks are not of the same magnitude, something which is sensible because, in economic theory, the long-run adjustment is usually higher than the short-run one. Anyway, the hypothesis that liquidity shocks are priced is strongly supported. The second hypothesis, that credit rating announcements adversely affect liquidity, is also well supported, with an impact of 20.7285, and carries a t-statistic of 7.842577. Relatively speaking the effect of credit rating announcements on the CAD log return is almost $16 \%$ of the effect of straight and ordinary liquidity shocks. The adjustment to the long-run is 7I.9I282 open days, an adequate figure and a relatively fast adjustment. The coefficient on the $A R(1)$ variable is negative and significant. Finally, the adjusted R-Square is quite high for daily data and is 0.977498 .

In Tables IO to 12 the empirical results for the cases of the Swiss franc, euro, and British pound are respectively presented. The two regressions in each table, and for a given pair of currencies, produce similar results. We shall examine the 4 day window regression because it has the lower values of the information criteria (Akaike, I973; Schwarz, 1978; Hannan \& Quinn, 1979). The short-term effects of the illiquidity shock are 107.0997, 92.26169, and 78.9026I respectively for the CHF, Euro, and GBP, and are highly significant statistically with actual p-values less than 0.00005. A Wald test for the nulls of equality fails to reject these nulls with a minimum actual two-tailed p-value of 0.0644 (Table I4). From this is inferred that the short-run and the long-run effect of liquidity shocks are of the same magnitude, something which is rather challenging because, in economic theory, the long-run adjustment is usually higher than the short-run one. However, a sign test, where 5 cases out of 5 have positive signs, produces a z-statistic of 3.13, which is significant in a normal distribution. Therefore, with a sign test, the long-run impact is higher than the short one. Anyway, the hypothesis that liquidity shocks are priced is strongly supported. The second hypothesis, that credit rating announcements adversely affect liquidity, is also well supported, with an impact varying between 6.333216, 5.88009I, and 9.664674 respectively, and they carry t-statistics of 2.572247, 3.4I4618, and I2.15186. Relatively speaking the effects of credit rating announcements on the three respective log-returns is between $5.9 \%, 6.4 \%$, and $12 \%$, of the effects of straight and ordinary liquidity shocks. The adjustments to the long-run, which are measured by their respective $-1 / c(3)$, are $54.03935,68.32255$, and IOI.407I open days respectively. The coefficients on the $A R(1)$ variable 
are negative and highly significant. Finally, the adjusted R-Squares are quite high for daily data and are 0.990232, 0.987465, and 0.989914 respectively.

Table I3 reproduces the results about the Japanese yen. The R-Squared is very small at around $2.6 \%$. The short-run impact of liquidity shocks is too elevated. The long-run impact of liquidity shocks is huge. The differential and interactive impact of credit rating news are insignificant. The AR(I) specification is not supported. The adjustment to the long- run is very short (29 open days). These empirical results are so strange that we surmise that they are likely to be outliers and thus we decide to ignore them.

Next, principal components are extracted from two sets of variables. The first set is that of the natural logs of the US dollar cross rates, and the first principal component accounts for $77.70 \%$ of the total variability and is denoted by LNALL, while the second set is for the Bid-Ask spreads, and the first principal component accounts for $77.95 \%$ of the total variability and is denoted by SALL. The JPY pairs are excluded, leaving five currency pairs. Then first differences are applied on the derived first principal components, producing $\triangle \mathrm{LNALL}$ and $\triangle \mathrm{SALL}$. Finally, all variables are replaced in the econometric model (4), LNALL in place of the five $L O G(B I D * * *)$, SALL in place of the five $S * * *$, and $\triangle \mathrm{LNALL}$ and $\triangle \mathrm{SALL}$ in place of the five $\Delta L O G(B I D * * *)$, and the five $\Delta S * * *$. The results of estimating the model appear in Table I5. The left panel utilizes the 3-day window, while the right panel utilizes the 5-day window. Comparing the three information criteria, the model with a 5-day window turns out to be superior, although the parameters take very close values. The analysis will be restricted to the right 4-day window panel.

The two hypotheses under scrutiny are still the same: (I) liquidity shocks are priced in the Lebanese daily foreign exchange market, meaning that illiquidity increases the log-returns on the principal component of the currency pairs, and (2) sovereign credit rating announcements generate instability and raise the liquidity shocks. An implicit hypothesis is formulated in the model of equation (4), which is that sovereign credit rating announcements have an ephemeral impact on the foreign exchange rate market, lasting the length in days of the event window. The empirical results are supportive of the two hypotheses. However, the long-run and the short-run impacts are statistically unequal, with a p-value of 0.0I76 for the null of equality, but are close to $+\mathrm{I}$. The impact of the credit rating news is statistically highly significant (t-statistic: 5.9I26I6), and the adjustment in the long-run takes a reasonable pace (91.83 open days). Finally, the ratio of the impact of credit rating news on the impact of general liquidity shocks is $10.48 \%$.

As a summary, liquidity shocks are priced in the daily foreign exchange market of Lebanon. This means that higher illiquidity increases the log-return of a currency, or that there is a positive relation between illiquidity and currency log-returns. This holds true maybe because the spreads or the illiquidity are higher in the Lebanese context compared to other markets. The interactive effects of rating announcements with illiquidity are all positive, as expected, and they are estimated to be from $5.9 \%$ to $19 \%$ of the direct effect of illiquidity measured alone. Therefore, rating announcements, through their interactive effect with illiquidity, increase uncertainty in the market. As for the equality between the short-run and long-run effects of illiquidity, the data provides mixed results although theoretically the long-run effect should be stronger. Hence, it seems that there is little evidence for overshooting and undershooting of the price of illiquidity.

\section{Conclusion}

This paper has undertaken six composite event studies covering six foreign exchange rates. The frequency is daily, from early January 2010 to October 16, 2019, this later date being at the eve of the general uprising of the populace, against the ruling political representatives, that has disrupted the economy. The composite event is the sovereign credit rating announcements that consisted of a slow deterioration since 2016. The channel of transmission is through illiquidity within the foreign exchange rate market. It is assumed that the financial uncertainty of such bad news engendered a sprout of illiquidity that aggravated the effect of general illiquidity shocks. The event window is studied to take either 3 , or 4 , or 5 days. The size of the window is not an important issue. Nonetheless, the 5-day window is marginally preferred. The goodness-of-fit statistics are elevated. It is argued that the underlying foreign exchange rates are cross rates, and not prices of the domestic currency. In other terms, these foreign rates are against the US dollar in the Lebanese market, and the ask, bid, and mid prices are those about to the US dollar against the six major currencies: the Australian dollar, the Canadian dollar, the Swiss franc, the euro, the British pound, and the Japanese yen. For credit rating announcements to be unexpected news, the reaction must be ephemeral and discounted quickly by the markets. The individual empirical results show a strong acceptance of the model. Only one currency pair provides strange results, and it is the Japanese yen. Moreover, extracting and relating the first principal components of the variables validate further the underlying hypotheses. The conclusion is that liquidity shocks are priced in the foreign exchange market, and that sovereign credit rating announcements initiate an additional uncertainty in the financial markets, that brings about higher illiquidity. An avenue for future research is to determine if favorable credit rating announcements increase liquidity, and thereby lower returns in the financial markets. There is one unexpected finding: the high goodness-of-fit of the regressions with daily data. Such data carry usually more noise. 


\section{References}

Acharya, V. V., \& Pedersen, L. H. (2005). Asset pricing with liquidity risk. Journal of Financial Economics, 77(2), 375-4IO.

Akaike, H. (1973). Maximum likelihood identification of Gaussian autoregressive moving average models. Biometrika, 60(2), 255-265.

Akbas, F., Armstrong, W. J., \& Petkova, R. (201I). Idiosyncratic volatility of liquidity and expected stock returns. Working Paper.

Amihud, Y. (2002). Illiquidity and stock returns: cross-section and time-series effects. Journal of Financial Markets, 5(I), 3I56.

Amihud, Y., Hameed, A., Kang, W., \& Zhang, H. (2015). The illiquidity premium: International evidence. Journal of Financial Economics, IIT(2), 350-368.

Amihud, Y., \& Mendelson, H. (1986a). Liquidity and stock returns. Financial Analysts Journal, 42(3), 43-48.

Amihud, Y., \& Mendelson, H. (1986b). Asset pricing and the bid-ask spread. Journal of Financial Economics, I7(2), $223-249$.

Amihud, Y., \& Mendelson, H. (2008). Liquidity, the value of the firm, and corporate finance. Journal of Applied Corporate Finance, 20(2), 32-45.

Amihud, Y., \& Mendelson, H. (2015). The pricing of illiquidity as a characteristic and as a risk. Multinational Finance Journal, I9(3), I49-I68.

Avramov, D., Cheng, S., \& Hameed, A. (2016). Time-varying liquidity and momentum profits. Journal of Financial and Quantitative Analysis, 5I(6), I897-I923.

Bai, J., \& Collin-Dufresne, P. (2019). The CDS-bond basis. Financial Management, 48(2), 4I7-439.

Banti, C. (2016). Illiquidity in the stock and foreign exchange markets: An investigation of their cross-market dynamics. Journal of Financial Research, $39(4), 4$ I -436.

Banti, C., \& Phylaktis, K. (20I5). FX market liquidity, funding constraints, and capital flows. Journal of International Money and Finance, 56, I I4-I34.

Banti, C., Phylaktis, K., \& Sarno, L. (2012). Global liquidity risk in the foreign exchange market. Journal of International Money and Finance, 3I(2), 267-29I.

Bekaert, G., Harvey, C. R., \& Lundblad, C. (2007). Liquidity and expected returns: Lessons from emerging markets. The Review of Financial Studies, 20(6), I783-I83I.

Betton, S., Eckbo, B. E., \& K. S. Thorburn. (2008). Corporate Takeovers, in B. E. Eckbo (ed) Handbook of corporate finance: Empirical Corporate Finance, Vol. 2, Amsterdam: Elsevier North-Holland, Chapter I5, 29I-430.

Chordia, T., Roll, R., \& Subrahmanyam, A. (2000). Commonality in liquidity. Journal of Financial Economics, 56(I), 3-28.

De Jong, F., \& Driessen, J. (2012). Liquidity risk premia in corporate bond markets. The Quarterly Journal of Finance, 2(02), I250006.

del Mar Miralles-Quirós, M., Miralles-Quirós, J. L., \& Oliveira, C. (2017). The role of liquidity in asset pricing: the special case of the Portuguese Stock Market. Journal of Economics, Finance and Administrative Science.

Dilidüzgün, M. Ö., Yılmaz, A. A., \& Selçuk, E. A. (2020). Spread Determinants in Corporate Bond Pricing: The Effect of Market and Liquidity Risks. Panoeconomicus, I-23.

Ellert, J. C. (1976). Mergers, antitrust law enforcement, and stockholder returns. The Journal of Finance, 3I(2), 7I5-732.

Fama, E. F., Fisher, L., Jensen, M. C., \& Roll, R. (1969). The adjustment of stock prices to new information. International Economic Review, IO(I), I-2I.

Foran, J., Hutchinson, M. C., \& O'Sullivan, N. (20I4). The asset pricing effects of UK market liquidity shocks: Evidence from tick data. International Review of Financial Analysis, 32, 85-94.

Foran, J., \& O'Sullivan, N. (20I4). Liquidity risk and the performance of UK mutual funds. International Review of Financial Analysis, 35, I78-I89.

Froot, K. A., \& Thaler, R. H. (1990). Anomalies: foreign exchange. Journal of Economic Perspectives, 4(3), 179-192.

Guo, H., Mortal, S., Savickas, R., \& Wood, R. (2017). Market illiquidity and the conditional equity premium. Financial Management, $46(3), 743-766$.

Hannan, E. J., \& Quinn, B. G. (1979). The determination of the order of an autoregression. Journal of the Royal Statistical Society: Series B (Methodological), 4I(2), I90-I95.

Ibbotson, R. G. (1975). The price performance of common stock new issues. Journal of Financial Economics, $2(3), 235-272$.

Jaffe, J. F. (1974). The effect of regulatory changes on insider trading. The Bell Journal of Economics and Management Science, 93-I2I.

Jun, S. G., Marathe, A., \& Shawky, H. A. (2003). Liquidity and stock returns in emerging equity markets. Emerging Markets Review, 4(I), I-24.

Kothari, S. P., \& Warner, J. B. (2007). Econometrics of event studies, in B. E. Eckbo (ed) Handbook of corporate finance: Empirical Corporate Finance, Vol. I Amsterdam: Elsevier North-Holland, Chapter I, 3-36. 
Kumar, G., \& Misra, A. K. (2019). Liquidity-adjusted CAPM-An empirical analysis on the Indian stock market. Cogent Economics \& Finance, $7(\mathrm{I})$, I57347I.

Malkiel, B. G., \& Fama, E. F. (I970). Efficient capital markets: A review of theory and empirical work. The Journal of Finance, 25(2), 383-4I7.

Mancini, L., Ranaldo, A., \& Wrampelmeyer, J. (2013). Liquidity in the foreign exchange market: Measurement, commonality, and risk premiums. The Joumal of Finance, 68(5), I805-184I.

Marcelo, J. L. M., Miralles-Quirós, M. D. M., \& Oliveira, C. (2015). Systematic liquidity: commonality and inter-temporal variation in the Portuguese stock market. Cuadernos De Gestión, I5(2), 39-64.

Masulis, R. W. (1980). The effects of capital structure change on security prices: A study of exchange offers. Joumal of Financial Economics, 8(2), I39-I78.

Mehra, R., \& Prescott, E. C. (I985). The equity premium: A puzzle. Journal of Monetary Economics, I5(2), I45-I6I.

Newey, W. K., \& West, K. D. (1987). A Simple, Positive Semi-definite, Heteroskedasticity and Autocorrelation Consistent Covariance Matrix. Econometrica, 55(3), 703-708.

Oler, D. K., Harrison, J. S., \& Allen, M. R. (2008). The danger of misinterpreting short-window event study findings in strategic management research: An empirical illustration using horizontal acquisitions. Strategic Organization, 6(2), I5I-I84.

Pástor, L., \& Stambaugh, R. F. (2003). Liquidity risk and expected stock returns. Journal of Political Economy, III(3), 642685.

Schwarz, G. (1978). Estimating the dimension of a model. The annals of statistics, 6(2), 46I-464.

Zhong, X., \& Takehara, H. (2019). Pricing Liquidity Risk on the Tokyo Stock Exchange: Empirical Analysis Using Multiple Liquidity Measures. Journal of Accounting and Finance, I9(4).

\section{Appendix}

Table I. Sovereign credit rating announcements

\begin{tabular}{llll}
\hline Agency & Rating & Outlook & Date \\
\hline Moody's & CaaI & under review & Oct 01, 2019 \\
\hline Fitch & CCC & negative & Aug 23, 2019 \\
\hline S\&P & B- & negative & Mar 01, 2019 \\
\hline Moody's & CaaI & stable & Jan 21, 2019 \\
\hline Fitch & B- & negative & Dec I8, 2018 \\
\hline Moody's & B3 & negative & Dec I3, 2018 \\
\hline Moody's & B3 & stable & Aug 25, 2017 \\
\hline S\&P & B- & stable & Sep 02, 2016 \\
\hline Fitch & B- & stable & Jul I4, 2016 \\
\hline
\end{tabular}

Source: https://tradingeconomics.com/lebanon/rating, accessed on 28/I/2020

Table 2. Quotes of the US dollar cross rates in the Lebanese daily foreign exchange market

\begin{tabular}{|c|c|c|c|c|c|c|}
\hline & $\begin{array}{l}\text { BIDAUD } \\
/ 1507.5\end{array}$ & $\begin{array}{l}\text { BIDCAD } \\
/ 1507.5\end{array}$ & $\begin{array}{l}\text { BIDCHF } \\
/ \text { I507.5 }\end{array}$ & $\begin{array}{l}\text { BIDEUR } \\
/ \text { I507.5 }\end{array}$ & $\begin{array}{l}\text { BIDGBP } \\
/ 1507.5\end{array}$ & $\begin{array}{l}\text { BIDJPY } \\
/ 1507.5\end{array}$ \\
\hline Mean & $0.85668 \mathrm{I}$ & 0.868364 & I.03952I & I.22834I & 1.470813 & 0.010062 \\
\hline Median & 0.833443 & 0.876063 & I.03I536 & I. 228677 & I.522259 & 0.009552 \\
\hline Maximum & I.IOI532 & I.056882 & I.372604 & I.479297 & I.708604 & 0.013128 \\
\hline Minimum & 0.665320 & 0.679788 & 0.850580 & I.033426 & I.I98209 & 0.007947 \\
\hline Std. Dev. & 0.125225 & 0.107309 & 0.059493 & 0.112276 & 0.140479 & 0.001519 \\
\hline Skewness & 0.261338 & 0.087066 & 0.674583 & 0.125649 & -0.409629 & 0.643547 \\
\hline Kurtosis & I.587I90 & I.321618 & 5.718695 & I.690889 & I.755I74 & 2.006616 \\
\hline Jarque-Bera & 225.2203 & 282.5934 & 914.2465 & I76.3596 & 220.4120 & 262.3599 \\
\hline Probability & 0.000000 & 0.000000 & 0.000000 & 0.000000 & 0.000000 & 0.000000 \\
\hline
\end{tabular}




\begin{tabular}{llccccc}
\hline KPSS test & 4.827633 & 5.338559 & 0.911676 & 4.028609 & 4.352219 & 4.221391 \\
\hline Observations & 2382 & 2382 & 2382 & 2382 & 2382 & 2382
\end{tabular}

Notes: the critical p-values of the KPSS test are: 0.739000 (I\%), 0.463000 (5\%), and 0.347000 (I0\%).

Table 3. Log of quotes of the US dollar cross rates in the Lebanese daily foreign exchange market

\begin{tabular}{lllllll}
\hline & $\begin{array}{l}\text { LOG(BIDAUD } \\
\text { /I507.5) }\end{array}$ & $\begin{array}{l}\text { LOG(BIDCAD } \\
\text { /I507.5) }\end{array}$ & $\begin{array}{l}\text { LOG(BIDCHF } \\
\text { /I507.5) }\end{array}$ & $\begin{array}{l}\text { LOG(BIDEUR } \\
/ \text { I507.5) }\end{array}$ & $\begin{array}{l}\text { LOG(BIDGBP } \\
/ \text { I507.5) }\end{array}$ & $\begin{array}{l}\text { LOG(BIDJPY } \\
/ \text { I507.5) }\end{array}$ \\
\hline Mean & -0.165270 & -0.148798 & $0.03715 \mathrm{I}$ & 0.201492 & 0.381098 & -4.609828 \\
\hline Median & -0.182190 & -0.132317 & 0.031049 & 0.205938 & 0.420195 & -4.650980 \\
\hline Maximum & 0.096702 & 0.055323 & 0.316709 & 0.391567 & 0.535676 & -4.333031 \\
\hline Minimum & -0.407487 & -0.385975 & -0.161836 & 0.032880 & 0.180828 & -4.834969 \\
\hline Std. Dev. & 0.145164 & 0.123810 & 0.056549 & 0.091365 & 0.097989 & 0.145922 \\
\hline Skewness & 0.149074 & 0.029706 & 0.328269 & 0.035470 & -0.493505 & 0.507264 \\
\hline Kurtosis & 1.539215 & 1.308447 & 5.103743 & 1.650369 & 1.805232 & 1.906571 \\
\hline Jarque-Bera & 220.6115 & 284.3395 & 482.0351 & 181.2838 & 238.3647 & 220.8168 \\
\hline Probability & 0.000000 & 0.000000 & 0.000000 & 0.000000 & 0.000000 & 0.000000 \\
\hline KPSS test & 4.891981 & 5.322041 & 0.867987 & 4.008655 & 4.370390 & 4.227786 \\
\hline Observations & 2382 & 2382 & 2382 & 2382 & 2382 & 2382 \\
\hline
\end{tabular}

Table 4. Bid-Ask spreads for the quotes of the US dollar cross rates in the Lebanese daily foreign exchange market

\begin{tabular}{|c|c|c|c|c|c|c|}
\hline & SAUD/I507.5 & SCAD/I507.5 & SCHF/I507.5 & SEUR/I507.5 & SGBP/I507.5 & SJPY/I507.5 \\
\hline Mean & 0.007420 & $0.00752 \mathrm{I}$ & 0.009003 & 0.010639 & 0.012739 & $8.7 \mathrm{IE}-05$ \\
\hline Median & 0.007217 & 0.007589 & 0.008935 & 0.010647 & 0.013184 & 7.96E-05 \\
\hline Maximum & 0.009539 & 0.009154 & 0.011887 & 0.012809 & 0.014793 & 0.000119 \\
\hline Minimum & 0.005758 & $0.00589 \mathrm{I}$ & 0.007363 & 0.008949 & $0.01038 \mathrm{I}$ & $6.63 \mathrm{E}-05$ \\
\hline Std. Dev. & 0.001085 & 0.000929 & 0.000515 & 0.000972 & 0.001217 & I.34E-05 \\
\hline Skewness & 0.261135 & 0.087008 & 0.675188 & 0.125549 & -0.409368 & 0.597992 \\
\hline Kurtosis & I.5869II & I.321522 & 5.718446 & 1.690553 & I.755I58 & 2.088418 \\
\hline Jarque-Bera & 225.2567 & 282.6212 & 914.4365 & 176.4369 & 220.3312 & 224.4401 \\
\hline Probability & 0.000000 & 0.000000 & 0.000000 & 0.000000 & 0.000000 & 0.000000 \\
\hline KPSS test & 4.827704 & 5.338208 & 0.911642 & 4.028756 & 4.351794 & 4.203205 \\
\hline Observations & 2382 & 2382 & 2382 & 2382 & 2382 & 2382 \\
\hline
\end{tabular}

Table 5. Change in the Bid-Ask spreads for the quotes of the US dollar cross rates in the Lebanese daily foreign exchange market

\begin{tabular}{|c|c|c|c|c|c|c|}
\hline & $\begin{array}{l}\Delta(\text { SAUD } \\
/ \text { I507.5) }\end{array}$ & $\begin{array}{l}\Delta(\mathrm{SCAD} \\
/ \mathrm{I} 507.5)\end{array}$ & $\begin{array}{l}\Delta(\mathrm{SCHF} \\
/ \mathrm{I} 507.5)\end{array}$ & $\begin{array}{l}\Delta(\text { SEUR } \\
/ \text { I507.5) }\end{array}$ & $\begin{array}{l}\Delta(\mathrm{SGBP} \\
/ \mathrm{I} 507.5)\end{array}$ & $\begin{array}{l}\Delta(\mathrm{SJPY} \\
/ \mathrm{I} 507.5)\end{array}$ \\
\hline Mean & $-8.39 \mathrm{E}-07$ & $-7.49 \mathrm{E}-07$ & I.23E-07 & $-1.22 \mathrm{E}-06$ & $-\mathrm{I} .26 \mathrm{E}-06$ & $-5.57 \mathrm{E}-09$ \\
\hline Median & 0.000000 & 0.000000 & 0.000000 & 0.000000 & 0.000000 & 0.000000 \\
\hline Maximum & 0.000882 & 0.000232 & 0.001360 & 0.000292 & 0.000318 & $6.63 \mathrm{E}-06$ \\
\hline Minimum & -0.000829 & -0.000285 & -0.000803 & -0.000338 & -0.000862 & $-6.63 \mathrm{E}-06$ \\
\hline Std. Dev. & $5.78 \mathrm{E}-05$ & 4.IOE-05 & $6.36 \mathrm{E}-05$ & $6.14 \mathrm{E}-05$ & 7.17E-05 & 3.8IE-06 \\
\hline Skewness & 0.014147 & -0.198212 & 3.280730 & -0.299302 & -1.048708 & $-5.42 \mathrm{E}-05$ \\
\hline Kurtosis & 44.81585 & 6.034994 & I04.7858 & 5.226298 & $\mathrm{I} 4.38422$ & 3.036990 \\
\hline Jarque-Bera & I73472.4 & 929.4173 & I032104. & 527.2653 & I3293.88 & $0.13574 \mathrm{I}$ \\
\hline Probability & 0.000000 & 0.000000 & 0.000000 & 0.000000 & 0.000000 & 0.934381 \\
\hline $\begin{array}{l}\text { p-value of a } \\
\text { t-test on the } \\
\text { mean }\end{array}$ & 0.4789 & 0.3730 & $0.925 \mathrm{I}$ & 0.3337 & 0.3924 & $0.943 \mathrm{I}$ \\
\hline
\end{tabular}




\begin{tabular}{lllllll}
\hline KPSS test & $0.12697 \mathrm{I}$ & $0.08588 \mathrm{I}$ & $0.06 \mathrm{I} 9 \mathrm{I} 4$ & 0.058942 & $0.05 \mathrm{I} 080$ & $0.102 \mathrm{I} 47$ \\
\hline Observations & $238 \mathrm{I}$ & $238 \mathrm{I}$ & $238 \mathrm{I}$ & $238 \mathrm{I}$ & $238 \mathrm{I}$ & $238 \mathrm{I}$ \\
\hline
\end{tabular}

Table 6. log-returns of the US dollar cross rates in the daily Lebanese foreign exchange market

\begin{tabular}{|c|c|c|c|c|c|c|}
\hline & $\begin{array}{l}\Delta(\text { LOG } \\
(\text { BIDAUD) })\end{array}$ & $\begin{array}{l}\Delta(\text { LOG } \\
(\text { BIDCAD }))\end{array}$ & $\begin{array}{l}\boldsymbol{\Delta ( \mathrm { LOG }} \\
(\mathrm{BIDCHF}))\end{array}$ & $\begin{array}{l}\Delta(\text { LOG } \\
(\text { BIDEUR)) }\end{array}$ & $\begin{array}{l}\Delta(\text { LOG } \\
(\text { BIDGBP) })\end{array}$ & $\begin{array}{l}\Delta \text { (LOG } \\
(\text { BIDJPY)) }\end{array}$ \\
\hline Mean & -0.000124 & -0.000101 & I.49E-05 & -0.000112 & $-0.00010 \mathrm{I}$ & $-6.66 \mathrm{E}-05$ \\
\hline Median & 0.000000 & 0.000000 & 0.000000 & 0.000000 & $-6.48 \mathrm{E}-05$ & 0.000000 \\
\hline Maximum & 0.131082 & 0.027630 & 0.149418 & 0.032096 & 0.024697 & $0.033 \mathrm{I} 6 \mathrm{I}$ \\
\hline Minimum & -0.121588 & -0.032808 & -0.075864 & -0.034300 & -0.069324 & -0.037298 \\
\hline Std. Dev. & 0.007713 & 0.005360 & 0.006852 & $0.00570 \mathrm{I}$ & 0.005685 & $0.0059 \mathrm{I} 4$ \\
\hline Skewness & 0.246770 & -0.077769 & $3.809 \mathrm{I} 42$ & -0.2 III3I & -I.I044I9 & -0.110063 \\
\hline Kurtosis & 64.24529 & 5.443076 & I06.6I33 & $5.43 \mathrm{I} 283$ & I5.54728 & $7.556 \mathrm{I} 43$ \\
\hline Jarque-Bera & 372153.2 & 594.5369 & I070830. & 604.1236 & I6I02.83 & 2064.218 \\
\hline Probability & 0.000000 & 0.000000 & 0.000000 & 0.000000 & 0.000000 & 0.000000 \\
\hline $\begin{array}{l}\text { p-value of a } \\
\text { t-test on the } \\
\text { mean }\end{array}$ & 0.4322 & 0.3567 & 0.9154 & 0.3381 & 0.3862 & 0.5829 \\
\hline KPSS test & 0.118923 & 0.078579 & 0.066042 & 0.056664 & 0.053052 & 0.162183 \\
\hline Observations & 2381 & 2381 & $238 \mathrm{I}$ & 2381 & 2381 & 2381 \\
\hline
\end{tabular}

Table 7. Percent Bid-Ask spreads of the US dollar cross rates in the daily Lebanese foreign exchange market

\begin{tabular}{lllllll}
\hline & $\begin{array}{l}\text { SAUD } \\
\text { /MIDAUD }\end{array}$ & $\begin{array}{l}\text { SCAD } \\
\text { /MIDCAD }\end{array}$ & $\begin{array}{l}\text { SCHF } \\
\text { /MIDCHF }\end{array}$ & $\begin{array}{l}\text { SEUR } \\
\text { /MIDEUR }\end{array}$ & $\begin{array}{l}\text { SGBP } \\
\text { /MIDGBP }\end{array}$ & $\begin{array}{c}\text { SJPY } \\
\text { /MIDJPY }\end{array}$ \\
\hline Mean & 0.008624 & 0.008623 & 0.008624 & 0.008624 & 0.008624 & 0.008622 \\
\hline Median & 0.008624 & 0.008623 & 0.008624 & 0.008624 & 0.008624 & 0.008660 \\
\hline Maximum & 0.008632 & 0.008632 & 0.008631 & 0.008629 & 0.008628 & 0.009397 \\
\hline Minimum & 0.008615 & 0.008615 & 0.008617 & 0.008618 & 0.008619 & 0.007886 \\
\hline Std. Dev. & $3.29 \mathrm{E}-06$ & $3.25 \mathrm{E}-06$ & $2.62 \mathrm{E}-06$ & $2.20 \mathrm{E}-06$ & $1.86 \mathrm{E}-06$ & 0.000280 \\
\hline Skewness & 0.055885 & 0.055197 & -0.045730 & -0.032629 & 0.003586 & -0.281744 \\
\hline Kurtosis & 2.488920 & 2.625352 & 2.368620 & 2.438520 & 2.451807 & 2.511976 \\
\hline Jarque-Bera & 27.16427 & 15.14039 & 40.39526 & 31.71224 & 29.83131 & 55.15187 \\
\hline Probability & 0.000001 & 0.000516 & 0.000000 & 0.000000 & 0.000000 & 0.000000 \\
\hline $\begin{array}{l}\text { p-value of a } \\
\text { t-test on } \\
\text { mean }\end{array}$ & 0.0000 & 0.0000 & 0.0000 & 0.0000 & 0.0000 & 0.0000 \\
\hline KPSS test & & & & & & \\
\hline Observations & 2382 & 2382 & & & & \\
\hline
\end{tabular}

Table 8. Estimation of the econometric model (4) for the Australian dollar

\begin{tabular}{|c|c|}
\hline G(BIDAUD/I507.5)) & able: $\Delta(\mathrm{LOG}(\mathrm{BIDAUD} / \mathrm{I} 507.5))$ \\
\hline al Least Squares (Gauss- & Conditional Least Squares (Gauss- \\
\hline & \\
\hline & \\
\hline 80 after adjustments & justments \\
\hline nieved after 8 iterations & ce achieved after I iteration \\
\hline $\begin{array}{l}\text { HAC standard errors \& covariance using outer } \\
\text { product of gradients } \\
\text { (Prewhitening with lags }=2 \text { from SIC maxlags }= \\
\text { I3. Bartlett kernel. }\end{array}$ & $\begin{array}{l}\text { HAC standard errors \& covariance using outer product } \\
\text { of gradients } \\
\text { (Prewhitening with lags }=2 \text { from SIC maxlags }=\mathrm{I} 3 \text {, } \\
\text { Bartlett kernel. }\end{array}$ \\
\hline
\end{tabular}




\begin{tabular}{|c|c|c|c|c|c|c|c|}
\hline & \multicolumn{3}{|c|}{$\begin{array}{l}\text { Newey-West automatic bandwidth }=\mathrm{I} 4.6734, \\
\mathrm{NW} \text { automatic lag length }=8) \\
\Delta \\
(\mathrm{LOG}(\mathrm{BIDAUD} / \mathrm{I} 507.5))=\mathrm{C}(\mathrm{I})^{*} \Delta(\mathrm{SAUD} / \mathrm{I} 507 . \\
5)+\mathrm{C}(2)^{*} \Delta(\mathrm{SAUD} / \mathrm{I} 507.5)^{\star *} \mathrm{DDD} \\
+\mathrm{C}(3)^{\star *} \mathrm{LOG}(\mathrm{BIDAUD}(-\mathrm{I}) / \mathrm{I} 507.5)-\mathrm{C}(3)^{*} \mathrm{C}(4) \\
-\mathrm{C}(3)^{* *} \mathrm{C}(5)^{*} \mathrm{SAUD}(-\mathrm{I}) / \mathrm{I} 507.5+[\mathrm{AR}(\mathrm{I})=\mathrm{C}(6)]\end{array}$} & \multicolumn{4}{|c|}{$\begin{array}{l}\text { Newey-West automatic bandwidth }=\text { I5.I634, NW } \\
\text { automatic lag length }=8) \\
\Delta(\text { LOG }(\text { BIDAUD/I } 507.5))=\mathrm{C}(\mathrm{I})^{* *} \Delta(\mathrm{SAUD} / \mathrm{I} 507 . \\
5) \\
+\mathrm{C}(2)^{* *} \Delta(\mathrm{SAUD} / \mathrm{I} 507.5)^{*} \mathrm{DD} 5 \\
+\mathrm{C}(3)^{*} \mathrm{LOG}(\mathrm{BIDAUD}(-\mathrm{I}) / \mathrm{I} 507.5)-\mathrm{C}(3)^{* *} \mathrm{C}(4) \\
-\mathrm{C}(3)^{* *} \mathrm{C}(5)^{*} \mathrm{SAUD}(-\mathrm{I}) / \mathrm{I} 507.5+[\mathrm{AR}(\mathrm{I})=\mathrm{C}(6)]\end{array}$} \\
\hline & Coefficient Std. Error & t-Statistic & Prob. & Coefficient & $\begin{array}{l}\text { Std. } \\
\text { Error }\end{array}$ & t-Statistic & Prob. \\
\hline $\mathrm{C}(\mathrm{I})$ & I3I.703I & 44.43058 & 0.0000 & I3I.6398 & $\begin{array}{l}2.99078 \\
0\end{array}$ & 44.01521 & 0.0000 \\
\hline$C(2)$ & 27.30379 & 5.038453 & 0.0000 & 24.80212 & $\begin{array}{l}4.26985 \\
0\end{array}$ & 5.808662 & 0.0000 \\
\hline$C(3)$ & $\begin{array}{l}- \\
0.007330 \\
\end{array}$ & $\begin{array}{l}- \\
2.987150\end{array}$ & 0.0028 & -0.007432 & $\begin{array}{l}0.00246 \\
\mathrm{I}\end{array}$ & $-3.02027 \mathrm{I}$ & 0.0026 \\
\hline$C(4)$ & I. 170017 & $\begin{array}{l}- \\
58.62606 \\
\end{array}$ & 0.0000 & -I.I67482 & $\begin{array}{l}0.01966 \\
6 \\
\end{array}$ & -59.36672 & 0.0000 \\
\hline$C(5)$ & I35.I847 & 50.59498 & 0.0000 & I34.8870 & $\begin{array}{l}2.63856 \\
9\end{array}$ & 5I.I2I26 & 0.0000 \\
\hline \multirow[t]{8}{*}{$C(6)$} & - & -4.413156 & 0.0000 & -0.185417 & $\begin{array}{l}0.04279 \\
0\end{array}$ & $-4.33323 I$ & 0.0000 \\
\hline & R-squared & $\begin{array}{l}\text { Mean } \\
\text { dependent } \\
\text { variable }\end{array}$ & -0.000128 & R-squared & $\begin{array}{l}0.97899 \\
9\end{array}$ & $\begin{array}{l}\text { Mean } \\
\text { dependent } \\
\text { variable }\end{array}$ & -0.000128 \\
\hline & $\begin{array}{l}\text { Adjusted } \\
\text { R-squared }\end{array}$ & $\begin{array}{l}\text { S.D. } \\
\text { dependent } \\
\text { variable }\end{array}$ & 0.007712 & $\begin{array}{l}\text { Adjusted } \\
\text { R-squared }\end{array}$ & $\begin{array}{l}0.97895 \\
5\end{array}$ & $\begin{array}{l}\text { S.D. } \\
\text { dependent } \\
\text { variable }\end{array}$ & 0.007712 \\
\hline & $\begin{array}{l}\text { S.E. of } 0.00112 \mathrm{I} \\
\text { regression }\end{array}$ & $\begin{array}{l}\text { Akaike } \\
\text { informatio } \\
\mathrm{n} \text { criterion }\end{array}$ & -10.74624 & $\begin{array}{l}\text { S.E. of } \\
\text { regression }\end{array}$ & $\begin{array}{l}0.00111 \\
9\end{array}$ & $\begin{array}{l}\text { Akaike } \\
\text { information } \\
\text { criterion }\end{array}$ & -10.75057 \\
\hline & $\begin{array}{l}\text { Sum } \\
\text { squared } \\
\text { residuals }\end{array}$ & $\begin{array}{l}\text { Schwarz } \\
\text { informatio } \\
\mathrm{n} \text { criterion }\end{array}$ & -10.73168 & $\begin{array}{l}\text { Sum } \\
\text { squared } \\
\text { residuals }\end{array}$ & $\begin{array}{l}0.00297 \\
2\end{array}$ & $\begin{array}{l}\text { Schwarz } \\
\text { information } \\
\text { criterion }\end{array}$ & -10.73601 \\
\hline & $\begin{array}{l}\text { Log- } \\
\text { likelihood }\end{array}$ & $\begin{array}{l}\text { Hannan \& } \\
\text { Quinn } \\
\text { informatio } \\
\text { n criterion }\end{array}$ & -10.74094 & $\begin{array}{l}\text { Log } \\
\text { likelihood }\end{array}$ & $\begin{array}{l}12799.1 \\
8\end{array}$ & $\begin{array}{l}\text { Hannan \& } \\
\text { Quinn } \\
\text { information } \\
\text { criterion }\end{array}$ & -10.74527 \\
\hline & $\begin{array}{l}\text { Durbin- } \\
\text { Watson } \\
\text { statistic }\end{array}$ & $\begin{array}{l}\text { Wald F- } \\
\text { statistic }\end{array}$ & 3008.304 & $\begin{array}{l}\text { Durbin- } \\
\text { Watson } \\
\text { statistic }\end{array}$ & $\begin{array}{l}2.00873 \\
6\end{array}$ & $\begin{array}{l}\text { Wald } \\
\text { statistic }\end{array}$ & 3082.305 \\
\hline & $\begin{array}{l}\text { Prob. } \\
\text { (Wald F- } 0.000000 \\
\text { statistic) }\end{array}$ & & & $\begin{array}{l}\text { Prob. } \\
\text { (Wald F- } \\
\text { statistic) }\end{array}$ & $\begin{array}{l}0.00000 \\
0\end{array}$ & & \\
\hline
\end{tabular}

Table 9. Estimation of the econometric model (4) for the Canadian dollar.
Dependent Variable:
$\Delta(\mathrm{LOG}(\mathrm{BIDCAD} / \mathrm{I} 507.5))$
Method: ARMA Conditional Least Squares
(Gauss-Newton / Marquardt steps)
Sample (adjusted): 32382
Dependent Variable: $\Delta($ LOG(BIDCAD/I507.5))
Method: ARMA Conditional Least Squares
(Gauss-Newton / Marquardt steps)
Sample (adjusted): 32382
Included observations: 2380 after adjustments 


\begin{tabular}{|c|c|c|c|c|c|c|c|c|}
\hline & \multicolumn{4}{|c|}{$\begin{array}{l}\text { Included observations: } 2380 \text { after adjustments } \\
\text { Convergence achieved after } 3 \text { iterations } \\
\text { HAC standard errors \& covariance using outer } \\
\text { product of gradients } \\
\text { (Prewhitening with lags = I from SIC maxlags = } \\
\text { I3, Bartlett kernel, } \\
\text { Newey-West automatic bandwidth = I4.8588, } \\
\text { NW automatic lag length }=8 \text { ) } \\
\Delta(\mathrm{LOG}(\mathrm{BIDCAD} / \mathrm{I} 507.5))=\mathrm{C}(\mathrm{I})^{*} \\
\Delta(\mathrm{SCAD} / \mathrm{I} 507.5) \\
+\mathrm{C}(2)^{*} \Delta(\mathrm{SCAD} / \mathrm{I} 507.5)^{*} \mathrm{DDD} \\
+\mathrm{C}(3)^{*} \mathrm{LOG}(\mathrm{BIDCAD}(-\mathrm{I}) / \mathrm{I} 507.5)-\mathrm{C}(3)^{* *} \mathrm{C}(4) \\
-\mathrm{C}(3)^{*} \mathrm{C}(5)^{*} \mathrm{SCAD}(-\mathrm{I}) / \mathrm{I} 507.5+[\mathrm{AR}(\mathrm{I})=\mathrm{C}(6)]\end{array}$} & \multicolumn{4}{|c|}{$\begin{array}{l}\text { Convergence achieved after } 3 \text { iterations } \\
\text { HAC standard errors \& covariance using outer } \\
\text { product of gradients } \\
\text { (Prewhitening with lags = } 2 \text { from SIC maxlags = I3, } \\
\text { Bartlett kernel, } \\
\text { Newey-West automatic bandwidth = I7.2740, } \\
\text { NW automatic lag length = 8) } \\
\Delta(\mathrm{LOG}(\mathrm{BIDCAD} / \mathrm{I} 507.5))=\mathrm{C}(\mathrm{I})^{*} \Delta(\mathrm{SCAD} / \mathrm{I} 507.5) \\
+\mathrm{C}(2)^{*} \Delta(\mathrm{SCAD} / \mathrm{I} 507.5)^{\star} \mathrm{DD} 5 \\
+\mathrm{C}(3)^{*} \mathrm{LOG}(\mathrm{BIDCAD}(-\mathrm{I}) / \mathrm{I} 507.5)-\mathrm{C}(3)^{* *} \mathrm{C}(4) \\
-\mathrm{C}(3)^{* *} \mathrm{C}(5)^{*} \mathrm{SCAD}(-\mathrm{I}) / \mathrm{I} 507.5+[\mathrm{AR}(\mathrm{I})=\mathrm{C}(6)]\end{array}$} \\
\hline & Coefficient & $\begin{array}{l}\text { Std. } \\
\text { Error }\end{array}$ & t-Statistic & Prob. & Coefficient & $\begin{array}{l}\text { Std. } \\
\text { Error }\end{array}$ & t-Statistic & Prob. \\
\hline$C(I)$ & $129.36 \mathrm{I} 2$ & $\begin{array}{l}1.48895 \\
2 \\
\end{array}$ & 86.88068 & 0.0000 & 129.3057 & $\begin{array}{l}\text { I.59978 } \\
3\end{array}$ & 80.82703 & 0.0000 \\
\hline$C(2)$ & 21.95293 & $\begin{array}{l}2.64884 \\
2\end{array}$ & 8.287746 & 0.0000 & 20.72085 & $\begin{array}{l}2.64209 \\
7\end{array}$ & 7.842577 & 0.0000 \\
\hline$C(3)$ & $\begin{array}{l}- \\
0.013929\end{array}$ & $\begin{array}{l}0.00432 \\
6 \\
\end{array}$ & $\begin{array}{l}- \\
3.219845 \\
\end{array}$ & 0.0013 & -0.013906 & $\begin{array}{l}0.00422 \\
8 \\
\end{array}$ & $-3.2889 \mathrm{I} 2$ & 0.0010 \\
\hline$C(4)$ & $\begin{array}{l}- \\
\text { I.I529I7 }\end{array}$ & $\begin{array}{l}0.00922 \\
9\end{array}$ & - 124.9225 & 0.0000 & -I.I5I504 & $\begin{array}{l}0.00907 \\
2\end{array}$ & $-\mathrm{I} 26.923 \mathrm{I}$ & 0.0000 \\
\hline$C(5)$ & $\mathrm{I} 33.4720$ & $\begin{array}{l}\text { I.I7062 } \\
\text { I }\end{array}$ & I I4.0I 82 & 0.0000 & I33.3054 & $\begin{array}{l}\text { I.I5206 } \\
9\end{array}$ & I I5.7096 & 0.0000 \\
\hline \multirow[t]{8}{*}{$C(6)$} & $\begin{array}{l}- \\
0.187336 \\
\end{array}$ & $\begin{array}{l}0.02441 \\
6\end{array}$ & $\begin{array}{l}- \\
7.672547\end{array}$ & 0.0000 & -0.188100 & $\begin{array}{l}0.02454 \\
6\end{array}$ & -7.663247 & 0.0000 \\
\hline & R-squared & $\begin{array}{l}0.97747 \\
9\end{array}$ & $\begin{array}{l}\text { Mean } \\
\text { dependent } \\
\text { variable }\end{array}$ & $-\overline{0.000102}$ & R-squared & $\begin{array}{l}0.97754 \\
5\end{array}$ & $\begin{array}{l}\text { Mean } \\
\text { dependent } \\
\text { variable }\end{array}$ & -0.000102 \\
\hline & $\begin{array}{l}\text { Adjusted } \\
\text { R-squared }\end{array}$ & $\begin{array}{l}0.97743 \\
\mathrm{I}\end{array}$ & $\begin{array}{l}\text { S.D. } \\
\text { dependent } \\
\text { variable }\end{array}$ & 0.005361 & $\begin{array}{l}\text { Adjusted R- } \\
\text { squared }\end{array}$ & $\begin{array}{l}0.97749 \\
8\end{array}$ & $\begin{array}{l}\text { S.D. } \\
\text { dependent } \\
\text { variable }\end{array}$ & $0.00536 \mathrm{I}$ \\
\hline & $\begin{array}{l}\text { S.E. of } \\
\text { regression }\end{array}$ & $\begin{array}{l}0.00080 \\
5\end{array}$ & $\begin{array}{l}\text { Akaike } \\
\text { informati } \\
\text { on } \\
\text { criterion } \\
\end{array}$ & I I.40796 & $\begin{array}{l}\text { S.E. of } \\
\text { regression }\end{array}$ & $\begin{array}{l}0.00080 \\
4\end{array}$ & $\begin{array}{l}\text { Akaike } \\
\text { information } \\
\text { criterion }\end{array}$ & -II.4I09I \\
\hline & $\begin{array}{l}\text { Sum } \\
\text { squared } \\
\text { residuals }\end{array}$ & $\begin{array}{l}0.00154 \\
0\end{array}$ & $\begin{array}{l}\text { Schwarz } \\
\text { informati } \\
\text { on } \\
\text { criterion } \\
\end{array}$ & - & $\begin{array}{l}\text { Sum squared } \\
\text { residuals }\end{array}$ & $\begin{array}{l}0.00153 \\
5\end{array}$ & $\begin{array}{l}\text { Schwarz } \\
\text { information } \\
\text { criterion }\end{array}$ & -I I.39635 \\
\hline & $\begin{array}{l}\text { Log- } \\
\text { likelihood }\end{array}$ & $\begin{array}{l}\mathrm{I} 358 \mathrm{I} .4 \\
7\end{array}$ & $\begin{array}{l}\text { Hannan \& } \\
\text { Quinn } \\
\text { informati } \\
\text { on } \\
\text { criterion } \\
\end{array}$ & I I. 40266 & $\begin{array}{l}\text { Log } \\
\text { likelihood }\end{array}$ & $\begin{array}{l}\text { I3584.9 } \\
8\end{array}$ & $\begin{array}{l}\text { Hannan \& } \\
\text { Quinn } \\
\text { information } \\
\text { criterion }\end{array}$ & -I I.4056I \\
\hline & $\begin{array}{l}\text { Durbin- } \\
\text { Watson } \\
\text { statistic } \\
\end{array}$ & $\begin{array}{l}2.02510 \\
2\end{array}$ & $\begin{array}{l}\text { Wald F- } \\
\text { statistic }\end{array}$ & I0525.85 & $\begin{array}{l}\text { Durbin- } \\
\text { Watson } \\
\text { statistic }\end{array}$ & $\begin{array}{l}2.02498 \\
9\end{array}$ & $\begin{array}{l}\text { Wald } \\
\text { statistic }\end{array}$ & 9660.826 \\
\hline & $\begin{array}{l}\text { Prob. } \\
\text { (Wald F- } \\
\text { statistic) }\end{array}$ & $\begin{array}{l}0.00000 \\
0\end{array}$ & & & $\begin{array}{l}\text { Prob. (Wald } \\
\text { F-statistic) }\end{array}$ & $\begin{array}{l}0.00000 \\
0\end{array}$ & & \\
\hline
\end{tabular}


Table I0. Estimation of the econometric model (4) for the Swiss franc

\begin{tabular}{|c|c|c|c|c|c|c|c|c|}
\hline & \multicolumn{4}{|c|}{$\begin{array}{l}\text { Dependent Variable: } \\
\Delta \text { (LOG(BIDCHF/I 507.5)) } \\
\text { Method: ARMA Conditional Least Squares } \\
\text { (Gauss-Newton / Marquardt steps) } \\
\text { Sample (adjusted): } 32382 \\
\text { Included observations: } 2380 \text { after adjustments } \\
\text { Convergence achieved after I iteration } \\
\text { Coefficient covariance computed using } \\
\text { outer product of gradients } \\
\Delta(\mathrm{LOG}(\mathrm{BIDCHF} / \mathrm{I} 507.5))=\mathrm{C}(\mathrm{I})^{*} \Delta(\mathrm{SCHF} / \mathrm{I} 5 \\
07.5)+\mathrm{C}(2)^{*} \Delta(\mathrm{SCHF} / \mathrm{I} 507.5)^{*} \mathrm{DDD} \\
+\mathrm{C}(3)^{*} \mathrm{LOG}(\mathrm{BIDCHF}(-\mathrm{I}) / \mathrm{I} 507.5)-\mathrm{C}(3)^{* *} \mathrm{C}(4) \\
-\mathrm{C}(3)^{* *} \mathrm{C}(5)^{*} \mathrm{SCHF}(-\mathrm{I}) / \mathrm{I} 507.5+[\mathrm{AR}(\mathrm{I})=\mathrm{C}(6)]\end{array}$} & \multicolumn{4}{|c|}{$\begin{array}{l}\text { Dependent Variable: } \Delta(\mathrm{LOG}(\mathrm{BIDCHF} / \mathrm{I} 507.5)) \\
\text { Method: ARMA Conditional Least Squares } \\
\text { (Gauss-Newton / Marquardt steps) } \\
\text { Sample (adjusted): } 32425 \\
\text { Included observations: } 2423 \text { after adjustments } \\
\text { Convergence achieved after I iteration } \\
\text { Coefficient covariance computed using outer product of } \\
\text { gradients } \\
\Delta(\mathrm{LOG}(\mathrm{BIDCHF} / \mathrm{I} 507.5))=\mathrm{C}(\mathrm{I})^{*} \Delta(\mathrm{SCHF} / \mathrm{I} 507.5) \\
+\mathrm{C}(2)^{\star \star} \Delta(\mathrm{SCHF} / \mathrm{I} 507.5)^{*} \mathrm{DD} 5 \\
+\mathrm{C}(3)^{\star \star} \mathrm{LOG}(\mathrm{BIDCHF}(-\mathrm{I}) / \mathrm{I} 507.5)-\mathrm{C}(3)^{\star \star} \mathrm{C}(4) \\
-\mathrm{C}(3)^{\star \star} \mathrm{C}(5)^{*} \mathrm{SCHF}(-\mathrm{I}) / \mathrm{I} 507.5+[\mathrm{AR}(\mathrm{I})=\mathrm{C}(6)]\end{array}$} \\
\hline & Coefficient & $\begin{array}{l}\text { Std. } \\
\text { Error }\end{array}$ & t-Statistic & Prob. & Coefficient & $\begin{array}{l}\text { Std. } \\
\text { Error }\end{array}$ & t-Statistic & Prob. \\
\hline $\mathrm{C}(\mathrm{I})$ & I07.II39 & $\begin{array}{l}0.21730 \\
2\end{array}$ & 492.9270 & 0.0000 & 107.0997 & $\begin{array}{l}0.21627 \\
0\end{array}$ & 495.2129 & 0.0000 \\
\hline$C(2)$ & 6.900237 & $\begin{array}{l}3.31805 \\
6 \\
\end{array}$ & 2.079602 & 0.0377 & 6.333216 & $\begin{array}{l}2.46213 \\
3 \\
\end{array}$ & 2.572247 & 0.0102 \\
\hline$C(3)$ & $\begin{array}{l}- \\
0.018652 \\
\end{array}$ & $\begin{array}{l}0.00396 \\
8 \\
\end{array}$ & $\begin{array}{l}- \\
4.700743 \\
\end{array}$ & 0.0000 & -0.018505 & $\begin{array}{l}0.00392 \\
8 \\
\end{array}$ & -4.710769 & 0.0000 \\
\hline$C(4)$ & $\begin{array}{l}- \\
0.949360 \\
\end{array}$ & $\begin{array}{l}0.01187 \\
8 \\
\end{array}$ & $\begin{array}{l}- \\
79.92756 \\
\end{array}$ & 0.0000 & -0.948914 & $\begin{array}{l}0.01182 \\
5 \\
\end{array}$ & -80.24778 & 0.0000 \\
\hline$C(5)$ & I09.578I & $\begin{array}{l}\mathrm{I} .31707 \\
0\end{array}$ & 83.19836 & 0.0000 & 109.5362 & $\begin{array}{l}\text { I.3II9I } \\
6\end{array}$ & 83.49331 & 0.0000 \\
\hline$C(6)$ & $\begin{array}{l}- \\
0.096663\end{array}$ & $\begin{array}{l}0.02075 \\
6\end{array}$ & 4.657152 & 0.0000 & -0.101956 & $\begin{array}{l}0.02055 \\
3 \\
\end{array}$ & $-4.96060 \mathrm{I}$ & 0.0000 \\
\hline & R-squared & $\begin{array}{l}0.99030 \\
9\end{array}$ & $\begin{array}{l}\text { Mean } \\
\text { dependent } \\
\text { variable } \\
\end{array}$ & I.35E-05 & R-squared & $\begin{array}{l}0.99025 \\
2 \\
\end{array}$ & $\begin{array}{l}\text { Mean } \\
\text { dependent } \\
\text { variable } \\
\end{array}$ & 2.35E-05 \\
\hline & $\begin{array}{l}\text { Adjusted } \\
\text { R-squared }\end{array}$ & $\begin{array}{l}0.99028 \\
9\end{array}$ & $\begin{array}{l}\text { S.D. } \\
\text { dependent } \\
\text { variable }\end{array}$ & 0.006853 & $\begin{array}{l}\text { Adjusted R- } \\
\text { squared }\end{array}$ & $\begin{array}{l}0.99023 \\
2\end{array}$ & $\begin{array}{l}\text { S.D. } \\
\text { dependent } \\
\text { variable }\end{array}$ & 0.006804 \\
\hline & $\begin{array}{l}\text { S.E. of } \\
\text { regression }\end{array}$ & $\begin{array}{l}0.00067 \\
5\end{array}$ & $\begin{array}{l}\text { Akaike } \\
\text { informati } \\
\text { on } \\
\text { criterion } \\
\end{array}$ & I 1.76011 & $\begin{array}{l}\text { S.E. of } \\
\text { regression }\end{array}$ & $\begin{array}{l}0.00067 \\
2\end{array}$ & $\begin{array}{l}\text { Akaike } \\
\text { information } \\
\text { criterion }\end{array}$ & -I I.7689I \\
\hline & $\begin{array}{l}\text { Sum } \\
\text { squared } \\
\text { residuals }\end{array}$ & $\begin{array}{l}0.00108 \\
3\end{array}$ & $\begin{array}{l}\text { Schwarz } \\
\text { informati } \\
\text { on } \\
\text { criterion } \\
\end{array}$ & - & $\begin{array}{l}\text { Sum squared } \\
\text { residuals }\end{array}$ & $\begin{array}{l}0.00109 \\
3\end{array}$ & $\begin{array}{l}\text { Schwarz } \\
\text { information } \\
\text { criterion }\end{array}$ & -I I.75457 \\
\hline & $\begin{array}{l}\text { Log- } \\
\text { likelihood }\end{array}$ & $\begin{array}{l}\mathrm{I} 4000.5 \\
4\end{array}$ & $\begin{array}{l}\text { Hannan \& } \\
\text { Quinn } \\
\text { informati } \\
\text { on } \\
\text { criterion } \\
\end{array}$ & - & $\begin{array}{l}\text { Log } \\
\text { likelihood }\end{array}$ & $\begin{array}{l}\text { I4264.0 } \\
3\end{array}$ & $\begin{array}{l}\text { Hannan } \\
\text { Quinn } \\
\text { information } \\
\text { criterion }\end{array}$ & -I I.76369 \\
\hline & $\begin{array}{l}\text { Durbin- } \\
\text { Watson } \\
\text { statistic }\end{array}$ & $\begin{array}{l}2.01331 \\
7\end{array}$ & & & $\begin{array}{l}\text { Durbin- } \\
\text { Watson } \\
\text { statistic }\end{array}$ & $\begin{array}{l}2.01437 \\
9\end{array}$ & & \\
\hline
\end{tabular}


Table II. Estimation of the econometric model (4) for the euro

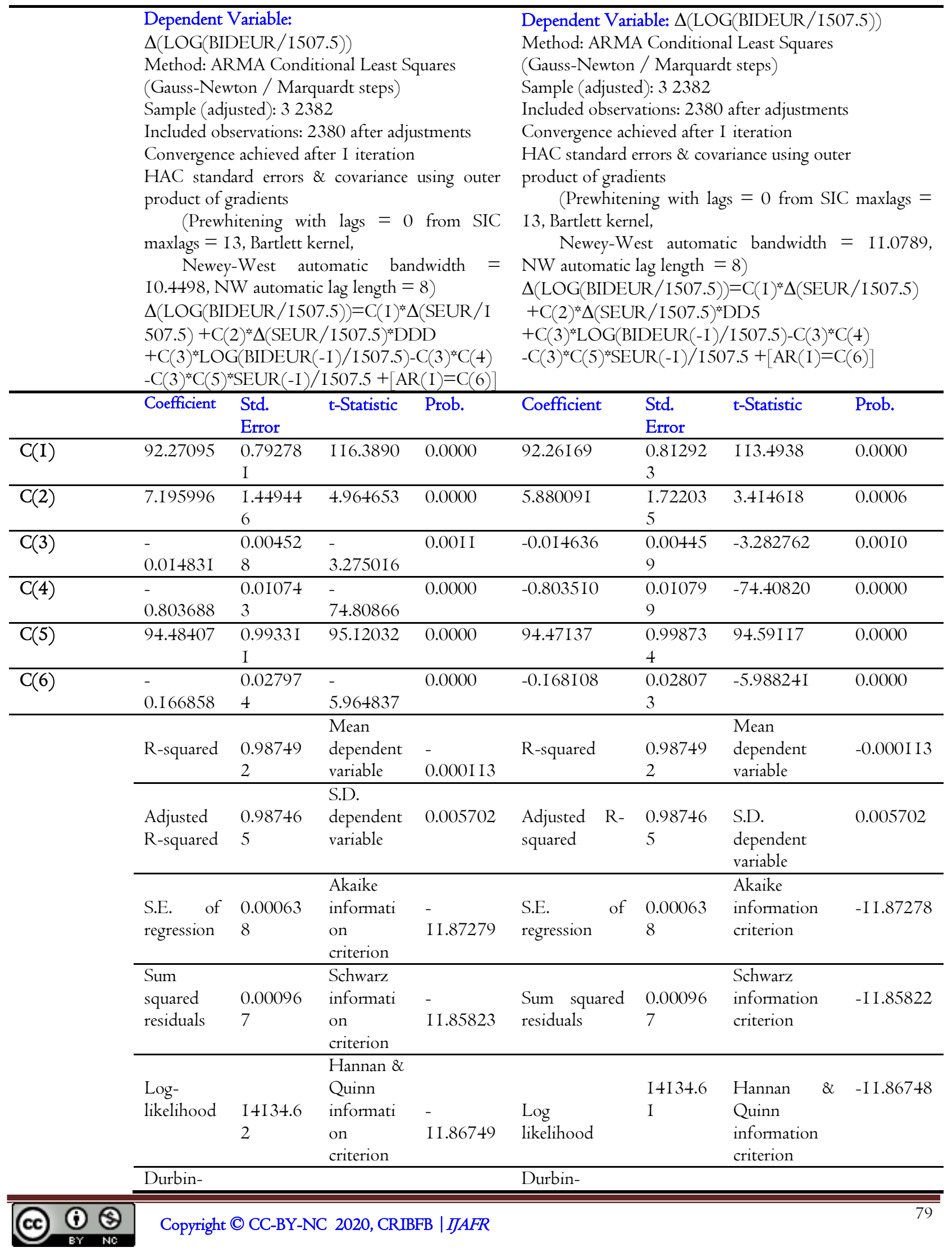




\begin{tabular}{llllllll}
\hline Watson & 2.00524 & Wald F- 33853.52 & Watson & $2.0054 \mathrm{I}$ & Wald & F- 32622.80 \\
statistic & 4 & statistic & & statistic & 7 & statistic & \\
\hline Prob. & & & & & & \\
(Wald F- & 0.00000 & & & Prob. (Wald & 0.00000 & & \\
statistic) & 0 & & & F-statistic) & 0 & & \\
\hline
\end{tabular}

Table I2. Estimation of the econometric model (4) for the British pound

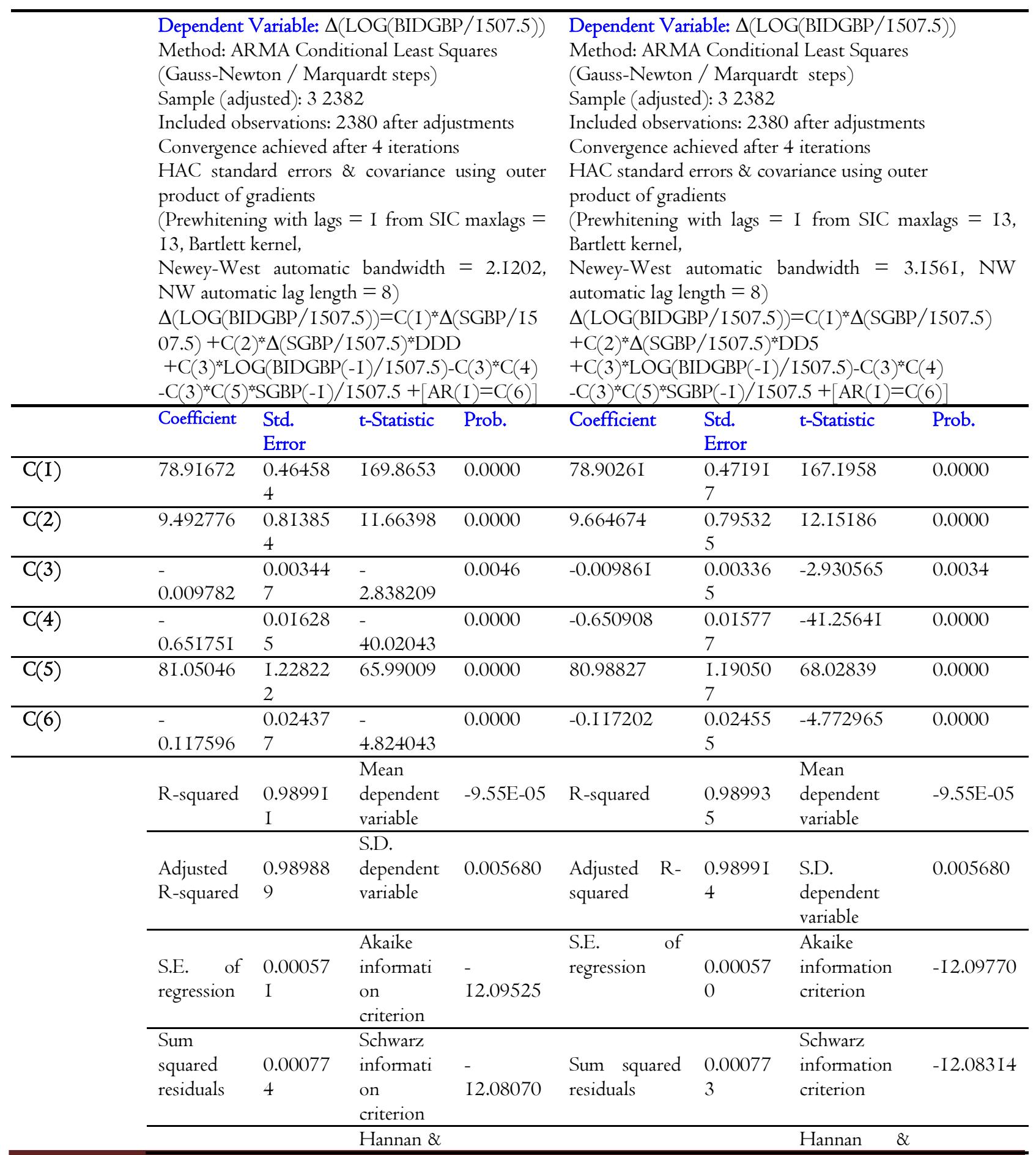




\begin{tabular}{|c|c|c|c|c|c|c|c|}
\hline $\begin{array}{l}\text { Log- } \\
\text { likelihood }\end{array}$ & $\begin{array}{l}\mathrm{I} 4399.3 \\
5\end{array}$ & $\begin{array}{l}\text { Quinn } \\
\text { informati } \\
\text { on } \\
\text { criterion }\end{array}$ & $\begin{array}{l}- \\
\mathrm{I} 2.08996\end{array}$ & $\begin{array}{l}\text { Log } \\
\text { likelihood }\end{array}$ & $\begin{array}{l}\mathrm{I} 4402.2 \\
6\end{array}$ & $\begin{array}{l}\text { Quinn } \\
\text { information } \\
\text { criterion }\end{array}$ & -12.09240 \\
\hline $\begin{array}{l}\text { Durbin- } \\
\text { Watson } \\
\text { statistic }\end{array}$ & $\begin{array}{l}2.00725 \\
6\end{array}$ & $\begin{array}{l}\text { Wald F- } \\
\text { statistic }\end{array}$ & 61623.68 & $\begin{array}{l}\text { Durbin- } \\
\text { Watson } \\
\text { statistic }\end{array}$ & $\begin{array}{l}2.00697 \\
7\end{array}$ & $\begin{array}{l}\text { Wald } \\
\text { statistic }\end{array}$ & 64522.45 \\
\hline $\begin{array}{l}\text { Prob. } \\
\text { (Wald F- } \\
\text { statistic) }\end{array}$ & $\begin{array}{l}0.00000 \\
0\end{array}$ & & & $\begin{array}{l}\text { Prob. (Wald } \\
\text { F-statistic) }\end{array}$ & $\begin{array}{l}0.00000 \\
0\end{array}$ & & \\
\hline
\end{tabular}

Table I3. Estimation of the econometric model (4) for the Japanese yen

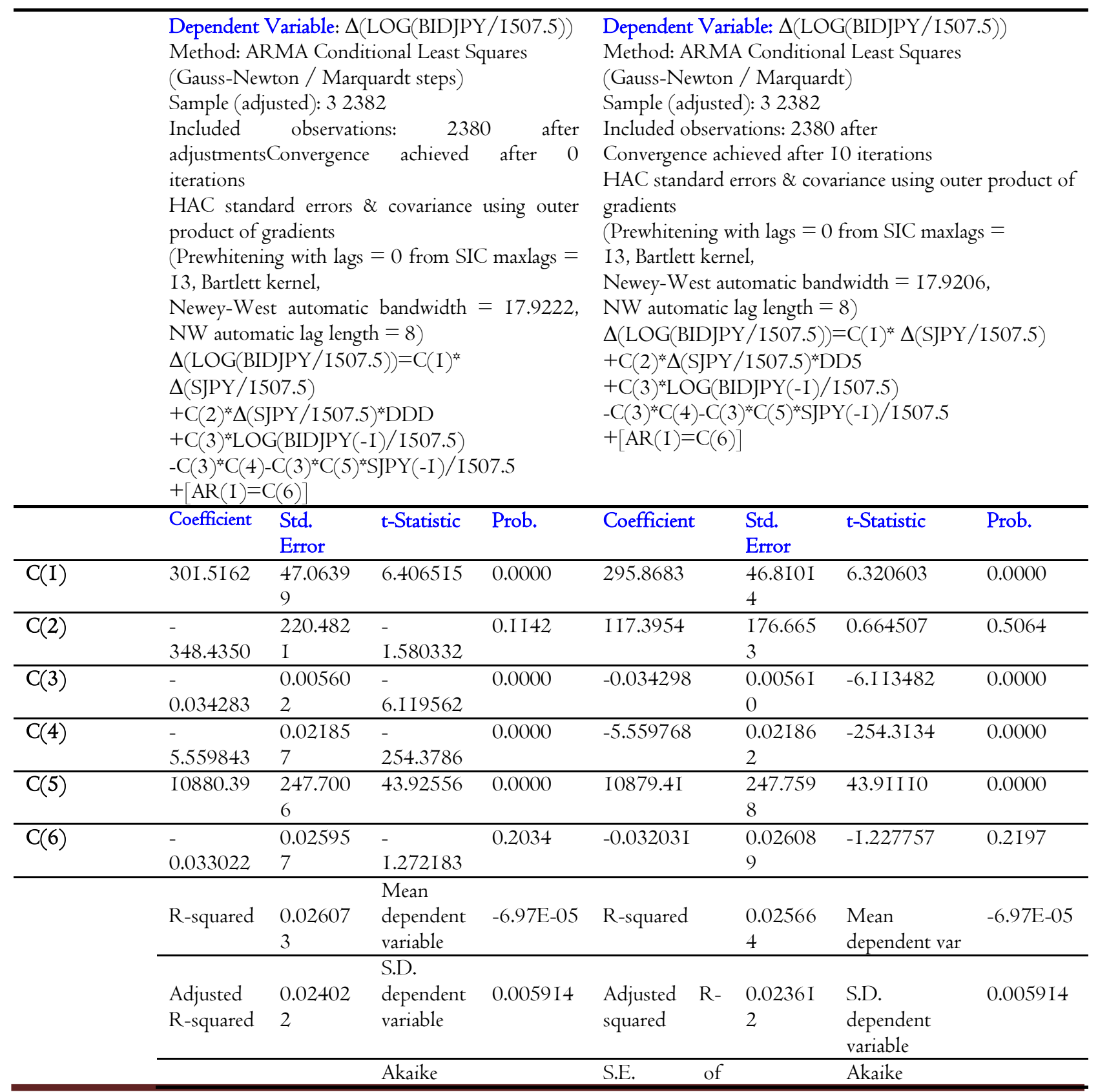




\begin{tabular}{|c|c|c|c|c|c|c|c|c|}
\hline $\begin{array}{l}\text { S.E. of } \\
\text { regression }\end{array}$ & $\begin{array}{l}0.00584 \\
2\end{array}$ & $\begin{array}{l}\text { informati } \\
\text { on } \\
\text { criterion }\end{array}$ & $\begin{array}{l}- \\
7.444946\end{array}$ & regression & $\begin{array}{l}0.00584 \\
3\end{array}$ & $\begin{array}{l}\text { information } \\
\text { criterion }\end{array}$ & & -7.444526 \\
\hline $\begin{array}{l}\text { Sum } \\
\text { squared } \\
\text { residuals }\end{array}$ & $\begin{array}{l}0.08102 \\
4\end{array}$ & $\begin{array}{l}\text { Schwarz } \\
\text { informati } \\
\text { on } \\
\text { criterion }\end{array}$ & $\begin{array}{l}- \\
7.430387\end{array}$ & $\begin{array}{l}\text { Sum squared } \\
\text { residuals }\end{array}$ & $\begin{array}{l}0.08105 \\
8\end{array}$ & $\begin{array}{l}\text { Schwarz } \\
\text { information } \\
\text { criterion }\end{array}$ & & -7.429967 \\
\hline $\begin{array}{l}\text { Log- } \\
\text { likelihood }\end{array}$ & $\begin{array}{l}8865.48 \\
6\end{array}$ & $\begin{array}{l}\text { Hannan \& } \\
\text { Quinn } \\
\text { informati } \\
\text { on } \\
\text { criterion }\end{array}$ & $\begin{array}{l}- \\
7.439647\end{array}$ & $\begin{array}{l}\text { Log } \\
\text { likelihood }\end{array}$ & $\begin{array}{l}8864.98 \\
6\end{array}$ & $\begin{array}{l}\text { Hannan } \\
\text { Quinn } \\
\text { information } \\
\text { criterion }\end{array}$ & $\&$ & -7.439227 \\
\hline $\begin{array}{l}\text { Durbin- } \\
\text { Watson } \\
\text { statistic } \\
\end{array}$ & $\begin{array}{l}1.99692 \\
9\end{array}$ & $\begin{array}{l}\text { Wald F- } \\
\text { statistic }\end{array}$ & 368065.8 & $\begin{array}{l}\text { Durbin- } \\
\text { Watson } \\
\text { statistic }\end{array}$ & $\begin{array}{l}1.99684 \\
6\end{array}$ & $\begin{array}{l}\text { Wald } \\
\text { statistic }\end{array}$ & F- & 367385.4 \\
\hline $\begin{array}{l}\text { Prob. } \\
\text { (Wald F- } \\
\text { statistic) }\end{array}$ & $\begin{array}{l}0.00000 \\
0\end{array}$ & & & $\begin{array}{l}\text { Prob. (Wald } \\
\text { F-statistic) }\end{array}$ & $\begin{array}{l}0.00000 \\
0\end{array}$ & & & \\
\hline
\end{tabular}

Table I4. Hypothesis tests on the six previous econometric models (Tables 8 to I3)

\begin{tabular}{|c|c|c|c|c|c|c|c|c|c|c|}
\hline \multirow{3}{*}{$\begin{array}{l}\text { Dependent } \\
\text { variable }\end{array}$} & \multicolumn{5}{|c|}{ DDD regression } & \multicolumn{5}{|c|}{ DD5 regression } \\
\hline & \multicolumn{2}{|c|}{$C(I)=C(5)$} & \multicolumn{2}{|c|}{$-\mathrm{I} / \mathrm{C}(3)=0$} & \multirow[b]{2}{*}{ Prob. } & \multicolumn{2}{|c|}{$C(I)=C(5)$} & \multicolumn{3}{|c|}{$-\mathrm{I} / \mathrm{C}(3)=0$} \\
\hline & F-value & Prob. & value & F-value & & F-value & Prob. & value & F-value & Prob. \\
\hline$\Delta \mathrm{LOG}(\mathrm{BIDAUD})$ & 0.736392 & 0.3909 & I36.4196 & 8.922892 & 0.0028 & 0.652166 & 0.4194 & 134.5526 & 9.122035 & 0.0026 \\
\hline$\Delta \mathrm{LOG}(\mathrm{BIDCAD})$ & $4.7 \mathrm{II} 45 \mathrm{I}$ & $0.030 \mathrm{I}$ & 7I.7906I & 10.36798 & 0.0013 & 4.258866 & 0.0392 & 71.91282 & I0.81694 & 0.0010 \\
\hline$\Delta \mathrm{LOG}(\mathrm{BIDCHF})$ & 3.473335 & 0.0625 & 53.61318 & 22.09698 & 0.0000 & 3.423323 & 0.0644 & 54.03935 & 22.19135 & 0.0000 \\
\hline$\Delta \mathrm{LOG}(\mathrm{BIDEUR})$ & 3.330059 & 0.0682 & 67.42658 & 10.72580 & $0.001 \mathrm{I}$ & 3.269536 & 0.0707 & 68.32255 & 10.77653 & 0.0010 \\
\hline$\Delta \mathrm{LOG}(\mathrm{BIDGBP})$ & 2.655845 & 0.1032 & 102.2285 & 8.055473 & 0.0046 & 2.702164 & 0.1003 & I0I.407I & $8.5882 \mathrm{I} 3$ & 0.0034 \\
\hline$\Delta \mathrm{LOG}(\mathrm{BIDJPY})$ & 1798.580 & 0.0000 & 29.16928 & 37.44904 & 0.0000 & I801.704 & 0.0000 & 29.15598 & 37.37466 & 0.0000 \\
\hline
\end{tabular}

Table 15. Regressions of the change in the extracted first principal component of the log returns on the change in the extracted first principal component of the spread

\begin{tabular}{|c|c|c|}
\hline & 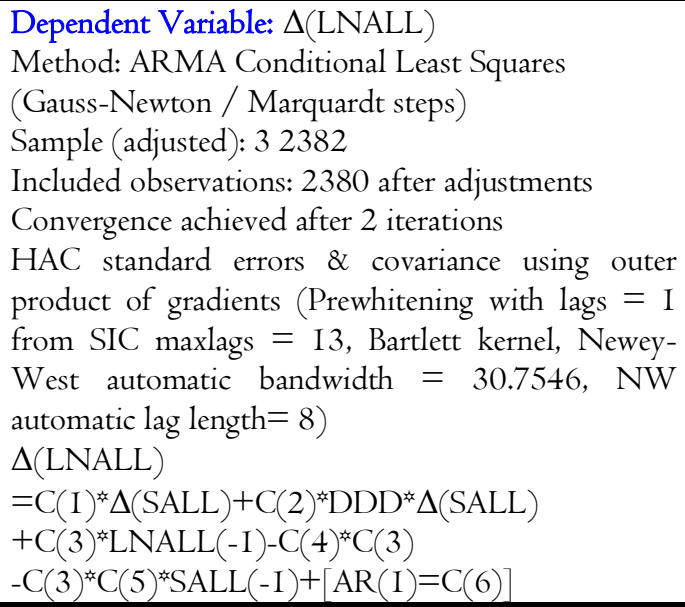 & $\begin{array}{l}\text { Dependent Variable: } \Delta \text { (LNALL) } \\
\text { Method: ARMA Conditional Least Squares } \\
\text { (Gauss-Newton / Marquardt steps) } \\
\text { Sample (adjusted): } 32382 \\
\text { Included observations: } 2380 \text { after adjustments } \\
\text { Convergence achieved after } 4 \text { iterations } \\
\text { HAC standard errors \& covariance using outer product } \\
\text { of gradients (Prewhitening with lags }=2 \text { from SIC } \\
\text { maxlags }=\mathrm{I} 3 \text {, Bartlett kernel, Newey-West automatic } \\
\text { bandwidth }=27.2246, \mathrm{NW} \text { automatic lag length= 8) } \\
\Delta(\mathrm{LNALL})=\mathrm{C}(\mathrm{I})^{*} \Delta(\mathrm{SALL})+\mathrm{C}(2)^{*} \mathrm{DD} 5^{*} \Delta(\mathrm{SALL}) \\
+\mathrm{C}(3)^{*} \mathrm{LNALL}(-\mathrm{I})-\mathrm{C}(4)^{*} \mathrm{C}(3) \\
-\mathrm{C}(3)^{* *} \mathrm{C}(5)^{*} \mathrm{SALL}(-\mathrm{I})+[\mathrm{AR}(\mathrm{I})=\mathrm{C}(6)]\end{array}$ \\
\hline & $\begin{array}{llll}\text { Coefficient } & \text { Std. Error } & \text { t-Statistic } & \text { Prob. }\end{array}$ & $\begin{array}{lll}\text { Coefficient } & \text { Std. } & \text { t-Statistic } \\
& \text { Error } & \\
\end{array}$ \\
\hline $\mathrm{C}(\mathrm{I})$ & $\begin{array}{llll}0.977274 & 0.01 I I 05 & 88.004 I 2 & 0.0000\end{array}$ & $\begin{array}{ll}0.01056 & 92.45646 \\
7 & \end{array}$ \\
\hline
\end{tabular}




\begin{tabular}{|c|c|c|c|c|c|c|c|c|}
\hline $\mathrm{C}(2)$ & O.III30I & 0.013924 & 7.993590 & 0.0000 & 0.102422 & $\begin{array}{l}0.01732 \\
3 \\
\end{array}$ & 5.912616 & 0.0000 \\
\hline$C(3)$ & $\overline{-} .010968$ & 0.004752 & $-\overline{2.308063}$ & $0.02 \mathrm{II}$ & -0.010890 & $\begin{array}{l}.0047 \mathrm{I} \\
0\end{array}$ & -2.311970 & 0.0209 \\
\hline $\mathrm{C}(4)$ & $\begin{array}{l}- \\
0.008048\end{array}$ & 0.018818 & $-\overline{0.427663}$ & 0.6689 & $-0.006 \mathrm{I} 43$ & $\begin{array}{l}0.0184 \mathrm{I} \\
0\end{array}$ & -0.333694 & 0.7386 \\
\hline$C(5)$ & I.00I94I & 0.010000 & I00.1942 & 0.0000 & I.00I044 & $\begin{array}{l}0.01019 \\
\mathrm{I}\end{array}$ & 98.22402 & 0.0000 \\
\hline \multirow[t]{8}{*}{$C(6)$} & $\begin{array}{l}- \\
0.084853\end{array}$ & 0.029835 & - 2.844046 & 0.0045 & -0.085622 & $\begin{array}{l}0.0298 \mathrm{I} \\
\mathrm{I}\end{array}$ & -2.872138 & $0.004 \mathrm{I}$ \\
\hline & R-squared & 0.991198 & $\begin{array}{l}\text { Mean } \\
\text { dependent } \\
\text { variable }\end{array}$ & -0.001772 & R-squared & $\begin{array}{l}0.99122 \\
7\end{array}$ & $\begin{array}{l}\text { Mean } \\
\text { dependent } \\
\text { variable }\end{array}$ & -0.001772 \\
\hline & $\begin{array}{l}\text { Adjusted } \\
\text { R-squared }\end{array}$ & 0.991179 & $\begin{array}{l}\text { S.D. } \\
\text { dependent } \\
\text { variable }\end{array}$ & 0.106276 & $\begin{array}{l}\text { Adjusted } \\
\text { R-squared }\end{array}$ & $\begin{array}{l}0.99120 \\
8\end{array}$ & $\begin{array}{l}\text { S.D. } \\
\text { dependent } \\
\text { variable }\end{array}$ & 0.106276 \\
\hline & $\begin{array}{l}\text { S.E. of } \\
\text { regression }\end{array}$ & $0.00998 \mathrm{I}$ & $\begin{array}{l}\text { Akaike } \\
\text { informatio } \\
\text { n criterion }\end{array}$ & -6.373679 & $\begin{array}{l}\text { S.E. of } \\
\text { regression }\end{array}$ & $\begin{array}{l}0.00996 \\
5\end{array}$ & $\begin{array}{l}\text { Akaike } \\
\text { information } \\
\text { criterion }\end{array}$ & -6.376994 \\
\hline & $\begin{array}{l}\text { Sum } \\
\text { squared } \\
\text { residuals }\end{array}$ & 0.236515 & $\begin{array}{l}\text { Schwarz } \\
\text { informatio } \\
\text { n criterion }\end{array}$ & $-6.359 \mathrm{I} 2 \mathrm{I}$ & $\begin{array}{l}\text { Sum } \\
\text { squared } \\
\text { residuals }\end{array}$ & $\begin{array}{l}0.23573 \\
3\end{array}$ & $\begin{array}{l}\text { Schwarz } \\
\text { information } \\
\text { criterion }\end{array}$ & -6.362435 \\
\hline & $\begin{array}{l}\text { Log- } \\
\text { likelihood }\end{array}$ & 7590.678 & $\begin{array}{l}\text { Hannan \& } \\
\text { Quinn } \\
\text { informatio } \\
\mathrm{n} \text { criterion }\end{array}$ & $-6.36838 \mathrm{I}$ & $\begin{array}{l}\text { Log } \\
\text { likelihood }\end{array}$ & $\begin{array}{l}7594.62 \\
2\end{array}$ & $\begin{array}{l}\text { Hannan } \\
\text { Quinn } \\
\text { information } \\
\text { criterion }\end{array}$ & -6.371695 \\
\hline & $\begin{array}{l}\text { Durbin- } \\
\text { Watson } \\
\text { statistic } \\
\end{array}$ & 2.008154 & $\begin{array}{l}\text { Wald F- } \\
\text { statistic }\end{array}$ & 6870.989 & $\begin{array}{l}\text { Durbin- } \\
\text { Watson } \\
\text { statistic }\end{array}$ & $\begin{array}{l}2.00817 \\
8\end{array}$ & $\begin{array}{l}\text { Wald } \\
\text { statistic }\end{array}$ & 4853.065 \\
\hline & $\begin{array}{l}\text { Prob. } \\
\text { (Wald F- } \\
\text { statistic) }\end{array}$ & 0.000000 & & & $\begin{array}{l}\text { Prob. } \\
\text { (Wald F- } \\
\text { statistic) }\end{array}$ & $\begin{array}{l}0.00000 \\
0\end{array}$ & & \\
\hline
\end{tabular}

\section{Copyrights}

Copyright for this article is retained by the author(s), with first publication rights granted to the journal. This is an open-access article distributed under the terms and conditions of the Creative Commons Attribution license (http://creativecommons.org/licenses/by/4.0/). 